EXTENSION

Institute of Food and Agricultural Sciences

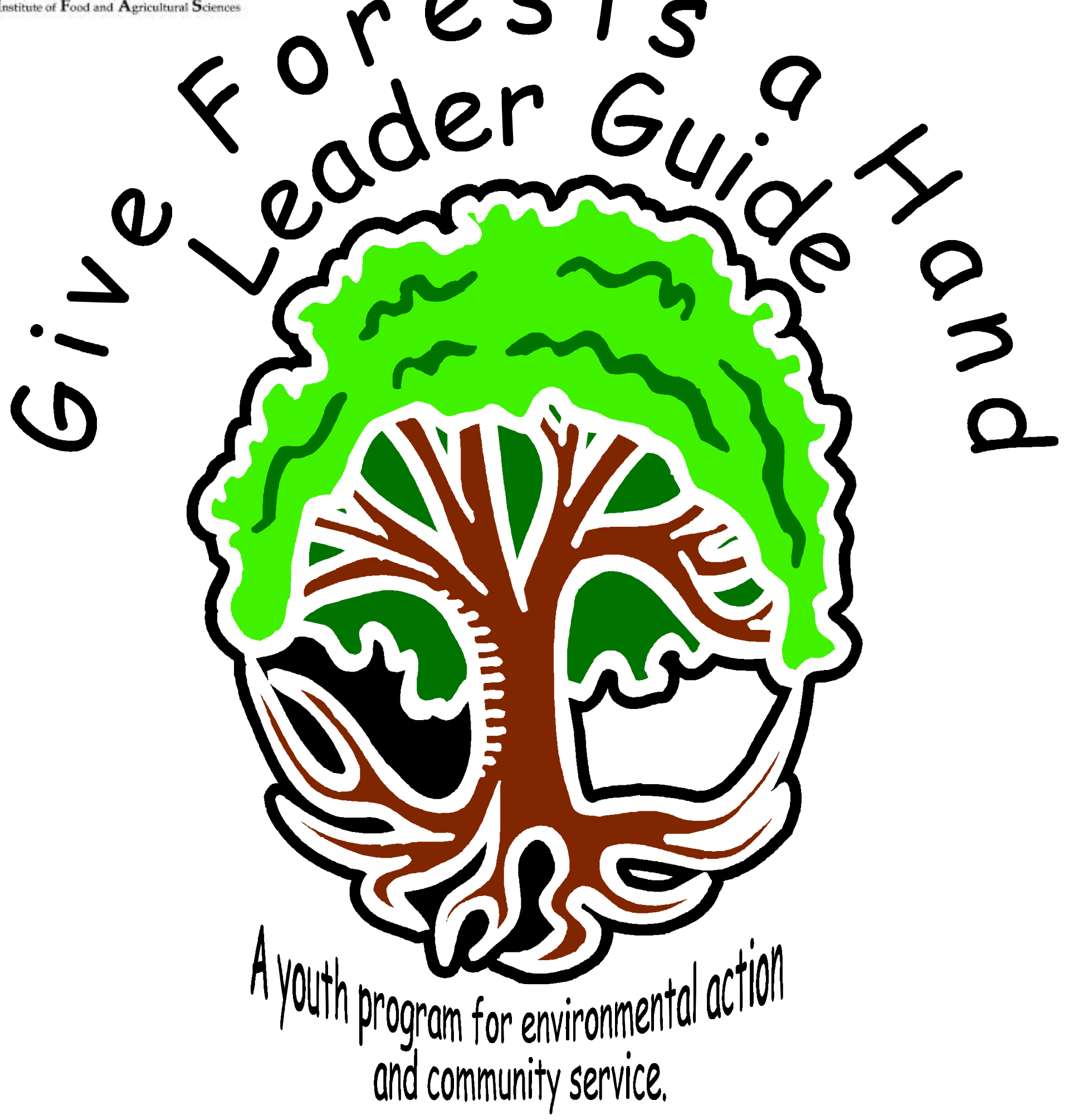

School of Forest Resources and Conservation Institute of Food and Agricultural Sciences University of Florida 


\title{
Give Forests a Hand Leader Guide
}

Written 6y: Alison Bowers, Program Ass is tant

I anice Easton, Graduate Student

Martha C. Monroe, Ass istant Professor and Extension Specialist

Lizzie Peme, Graduate Student

\author{
School of Forest Resources and Conservation \\ University of Florida \\ PO Box 110410 \\ Gaine sille, $\mathcal{F} \mathcal{L} \quad 32611-0410$ \\ Phone: $352-846-0878$
}

This guide is adapted, with permission, from Give Water a Hand Action Guide, a youth program for local environmental action. 71996. University of $\mathcal{W}$ isconsin $\mathcal{B}$ oard of Regents. For more information on Give Water $\mathcal{A}$ Hand call 1-800-W $\mathcal{A} \mathcal{T} 220$.

The development and evaluation of this material was supported by the U.S. Department of Agriculture, Cooperative $S$ tate Research, Education and Extension Service under Agreement $\mathcal{N}$ o.99-ERRP-1-0572; the US Department of the Interior, US Fish and Wildlife Service under Cooperative Agreement \# 1448-91100-00-g003, and the School of Forest Resources and Conservation, University of Florida.

COOPERATIVE EXTENSION SERVICE, UNIVERSITY OF FLORIDA, INSTITUTE OF FOOD AND AGRICULTURAL SCIENCES, Christine Taylor Waddill, Director, in cooperation with the United States Department of Agriculture, publishes this information to further the purpose of the May 8 and June 30, 1914 Acts of Congress; and is authorized to provide research, educational information and other services only to individuals and institutions that function without regard to race, color, age, sex, handicap or national origin. The information in this publication is available in alternate formats. Single copies of extension publications (excluding 4-H and youth publications) are available free to Florida residents from county extension offices. Information on copies for outof-state purchase is available from IFAS-Extension Bookstore, University of Florida, PO Box 110011, Gainesville, FL 32611-0011. Information about alternate formats is available from IFAS Communication Services, University of Florida, PO Box 110810, Gainesville, FL 32611-0810. This information was published in May 2002 as Circular 1270, Florida Cooperative Extension Service. Reviewed May 2002. 


\section{Acknowle dge ments}

$\mathcal{A}$ special thanks to the Advisory Committee who submitted case studies, revie wed Give Forests a Hand, and provided comments.

Elaine Andrews - Environmental Education $S$ pecialist, University of $\mathcal{W}$ isconsin Cooperative Extension, Environmental Resources Center, Madison, WI

Diane Cantrell-Deputy Chief, ODNR Division of Soil and Water Conservation and Adjunct Assistant Professor, Ohio State University, School of $\mathcal{N a t u r a l}$ Resources, Columbus, OH

Patricia Garner - Assistant Bureau Chief, Florida Division of Forestry, Tallahassee, FL

Michelle Harvey-Director, Science and $\mathcal{E} d u c a t i o n, S$ ociety of $\mathcal{A}$ me rican Foresters, Bethesda, $\mathcal{M D}$

Denver I ames. Assistant Director, Conservation Education, US DA Forest Service, Wasfington, $\mathcal{D C}$

Marsha Ke arney - Forest $\mathcal{S}$ upervisor, $\mathcal{N}$ ational Forests in Florida, US DA Forest Service, Tallahassee, $\mathcal{F} \mathcal{L}$

John Lilly - Extension $4 \mathcal{H} \mathcal{A g e n t}$, gefferson County Extension, University of Florida, Montic ello, $\mathcal{F} \mathcal{L}$

Ioe MacKenzie - Forest Management Assistance Program, Georgia Pacific Corporation, Gaine sville, $\mathcal{F} \mathcal{L}$

Peter Stortz-Extension $4 \mathcal{H}$, Fisheries, and $\mathcal{N}$ atural Resources Specialist, Unive rsity of $\mathcal{A l a s} K a, \mathcal{P a l m e} r, \mathcal{A K}$

Richard Thompson- Tucker. Executive Director, Merck Forest o Farmland Center, Rupert, $\mathcal{V T}_{\mathcal{T}}$

Michelle Youngquist - Idaho Forest Products Commission, Educational Coordinator, project Learning $\mathcal{T}$ ree Coordinator, $B$ oise, ID 


\section{Table of Contents}

I. Introduction

Welcome!

Overview of Give Forests a Hand

Introduction to Service Learning

II. Leaders'notes for the Youth Action Guide

Step 1: Focus on forests

Step 2: Discover a need for action

Step 3: Forests are more than trees

S tep 4: Explore your priorities

S tep 5: Choose a service project

Step 6: Project plan

S tep 7: Keep on track

Step 8: Celebrate success

I I . Activity bank

Icebreakers

Te am Builders

Decision Makers

Energizers

\section{Resources}

Federal natural resource agencies

Curriculum / environmental education / service le arning

Environmental / natural resource organizations

Professional / industry 


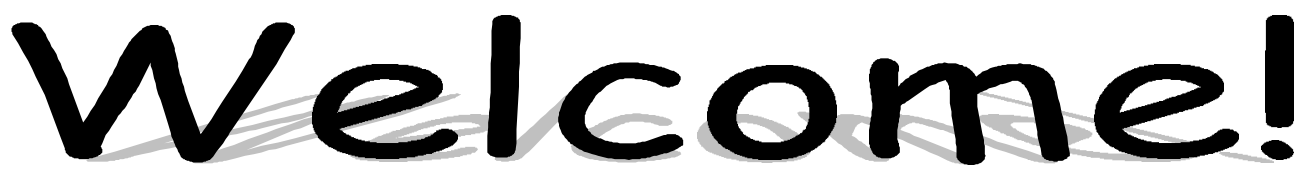

By opening this Leader Guide, you've taken the first step in fielping young people Give Forests a Hand. He re you will find step by step guidelines for helping your youth group or class (ages 9-14) make a differ. ence in the ir community and the environment.

We suggest you work with groups of 5 to 10 youth. This makes the group small enough so that everyone can participate, yet large enough so that youth can do a sizeable project and learn from working with others. If your group is too large, you might suggest splitting into two or more action groups.

Give Forests a Hand 6lends service le arning with the goals of environmental educa. tion to provide young people with opportunities to make decisions about how to help their communities.

Young people are encouraged to use the ir knowledge and talent in developing and im. plementing an action project. The process helps them gain a better understanding of the ir environment and see how the ir ac. tions make a difference.

How can my group make a difference? Youth across the country are making a dif. ference by increasing awareness, maintaining urban trees, building interpretative trails, and developing educational materials. Because forest issues are community issues, de termining what will help your community means getting to know the for. ests in your area! That's where you will help youth figure out what problems exist and the solutions that will make a differ. ence. Ideas, information, resources, and equipment are all around you. Help your group tap into these resources to Give Forests a Hand!

Why focus on forests?

Forests affect nearly every aspect of our lives. Forest products provide raw materials for our houses, furniture, fences, base ball bats, garden mulch, 6ooks, movie tickets, clothing, carpeting, and toothpaste. Forest ecosystems help to supply our water, maintain our climate, help purify the air, protect soils, and provide for wilderness experiences. Forests provide habitat for wildlife; are sources of food, fuel, and medicine for people; and help preserve biological diversity.

The actions of humans affect the benefits forests provide. If forest resources are to be sustained and enfanced, our actions must be directed at achieving desired outcomes in diverse ecosystems, environmental conditions, and social regimes; they must anticipate the effects of population growth and socialchange on future human needs. The present and future benefits from forests depend on the actions we take today.

(Society of American Foresters, 2001) 


\section{Overview of Give Forests a Hand}

The Leader Guide is for you, the youth le ader, and accompanies the Give Forests a Hand Youth Action Guide. As a le ader you won't necessarily know which direction the action projects will take, because your youth group or students will de termine that. As a le ader, your primary role is to help your group manage the process of conducting a service project. The Youth Action Guide allows youth to identify proble ms and carry out the ir own plans of ac. tion. Even though it is important for the m to do the work and make decisions, they will look to you for guidance and ass is. tance.

Forest education can and should be fun! And you don't have to know a lot about trees to get started. You canget help from your county's natural resource extension agent, soil and water conservation district, local forestry department, commercial foresters in your area, or any other resource people available in your community.

The next few pages follow the eight steps of the Youth Action Guide. The explanation for each step provides:

- Purpose and objectives for each step.

- Suggested preparation and materials needed for each step.
- Getting started provides tips with background information and instruc. tions to help with specific aspects of each step.

- Ideas for discussions with young people and suggestions for additional resources.

- $\mathcal{A}$ list of related activities found in the national environme ntal education curriculum Project Learning $\mathcal{T}$ ree $(\mathcal{P L T})$. These activities are a good way to provide background information to youth.

- $\mathcal{A}$ list of ice breakers, energizers, and decision making exercises for each step. The Activity Bank is found on pages $42-54$.

- A series of assessment questions for you to reflect on after completing each step.

This manual concludes with an annotated list of federal natural resource agencies, environmental education and service learn. ing materials, and a varie ty of environmental and natural resources or. ganizations.

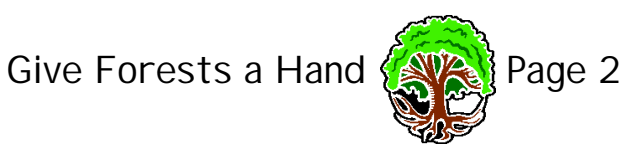




\section{Goals of Give Forest a Hand}

Goals

Involve young people in the investigation of forests and related environmental concerns.

Help young people develop projects that contribute to the ir community.

$S$ upport young people in using the ir skills and interests.

Establish links between youth and community natural resource professionals. Give youth an opportunity to le arn and practice life skills in decision making, communication, and citizenship.

Benefits for young people

Learn about community forest quality and conservation is sues.

Make a difference in the community.

Gain experience in natural resource management through partnerships with natural resource professionals.

Getting started

- Skim through the Le ader and Youth Action Guides to familiarize yourself with the steps.

- Review the project roles for youth, le aders, and community partners.

- Obtain a variety of maps of your area, such as road, topographic, plat, soil survey, and ae rial photos.

- Lookfor forest experts or organiza. tions who are willing to work with your group.

Project roles

Role of youth participant

A 1993 Louis Harris poll of over 10,000 students in grades 4-12 found that young people prefer after-school activities where they choose what they will do. The survey also found that kids want to work on environmental problems to help improve the ir communities, but they want to be in charge of deciding how.
The Give Forests a Hand materials are designed to help young people conduct action projects by providing simple steps and basic information. These guidelines will help youth make the ir own decisions about how to enfance the ir community forests.

Youth participants in Give Forests a Hand will:

- Investigate a localforest issues.

- Talk to experts about issues and possible projects.

- Choose a project based on their research that matches their own interests and $s$ kills.

- Develop a project plan.

- Complete a service project.

- Reflect on their experiences.

- Celebrate their success. 
Role of leader

The more young people plan and manage their own projects, the more they learn. The leader's role is not to be an expert on forest issues or the project planner, but to be a coach and mentor of young people. Follow your own judgment about when to urge the group on, when to hold them 6 ack, when to comfort them, and when to help pick up the pieces.

In Give Forests a Hand the le ader will:

- Act as a guide who monitors and encourages rather than directs.

- Create opportunities that foster le arning.

- Empower young people to be active ste wards of the environment.

- Help participants think through plans, recognize flaws, and adjust the ir plans.

- Linkyoung people to forest experts in the community, including project part. ners.

Role of project partners Project partners are individual experts and organizations that can help your group with planning and carrying out a project. You may already be working with a partner organization. If not, contact one of the organizations listed in the back of the Leader Guide. Some may even have service pro. grams your group could join.

Partners may be able to offer:

- Supplies such as tree seedlings, planting or pruning equipment, lumber, and other building supplies.

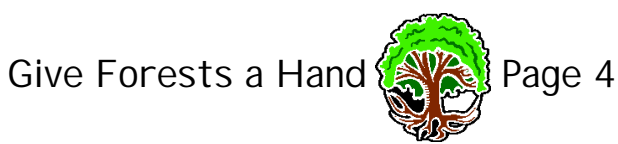

- Technical as sistance in planning and completing a project.

- Expertise in forest management and ecology.

- Materials such as posters, maps, or vide otapes.

Project time line

Help youth develop a timeline to kee $p$ on track and stick to a schedule. It may be helpful to think about the last available mee ting date, and plan backwards. In order to complete all steps in the Youth Action Guide, you will need a series of meetings, each an frour or two long, plus time in be. twe en to accomplish tasks.

Steps 1-6:6-10 meetings to research and identify a problem, then plan and prepare projects

Step 7:2-3 meetings to manage your project, depending on what you choose to do, plus time to conduct the project

Step 8: 1-2 meetings to wrap up, celebrate, and reflect on the experience Build in extra time for the unexpected! 
Safety first

Make sure youth are adequately supervised by you or another adult at all times. Your job as a leader is to think ahe ad and take all reasonable precautions.

Professional responsibility as well as concerns about legal liability require le aders of youth service projects to consider safety issues.

S peak with your organization's business manager, if there is one, or an insurance agent, to find out if you have liability cov. erage and if it is adequate for the project.
References

Cairn, R. (1992). Engaging young people as leaders of youth service programs. Generator: Iournal of Service le arning and Youth Leaderstip, 12 (2), 24.

Louis $\mathcal{H a r r i s}$ and $\mathcal{A s s o c i a t e s . ( 1 9 9 3 ) . \mathcal { A }}$ survey conducted for Pew Charitable Trusts. April 12-May 24, 1993.

Society of American Foresters (2001). Online - fttp://safnet.org

\section{Successful Leadership}

The key to successful youth service projects is involving young people in the de. velopment, planning, organization, and evaluation of projects. The youth service movement has learned much from young people about how to involve them as com. munity resources.

The following strategies will help you as a leader involve and e mpower youth:

Involve youth in setting realistic goals.

Arrange opportunities for young people to reflect on, learn from, and apply lessons from their experiences.

Acknowledge the skills, knowledge, and experiences young people alre ady have.

Give specific skills training or information as needed to help your group move the project ahead.

Askolder students or program veterans (including college students) for help. Involve youth as leaders who have never before had the chance to lead.

Define and maintain accountability.

Model befraviors you expect from young people. Expect the same from all staff and volunteers.

(Carin, 1992) 


\section{Introduction to Service Learning}

Give Forests a Hand Youth Action Guide uses a service le arning model to guide and direct young people through the process of planning and carrying out a service project.

As a leader, it will be helpfulfor you to know a little bit about this educational method -. what it is, how it works, and where to go for more information.

\section{Defining service le arning}

Service le arning combines service to the community with learning in a way that improves both youth and the community.

Service le arning:

- Is a method where young people le arn and develop through active participa. tion in thoughtfully organized service that is conducted in and meets the needs of communities.

- $\quad H e l p s$ foster civic responsibility.

- Is integrated into and enfinces the overall youth program or curriculum in which the participants are enrolled.

- Provides structured time for participants to reflect on the service experience.

(Le arn and Serve America, 2001 )
Service le arning frame work

The service le arning model can be captured in a simple frame work: Preparation, Action, Reflection, and Recognition (Duckenfield and Madden, 2000). The framework ass is $t$ both the novice and advanced practitioner as they strive to produce educational experiences for youth that will have lasting and meaningful impact.

Preparation consists of learning experiences that take place prior to the actual service. Youth are involved in ident if ying and analyzing a problem, selecting and planning a project, and receiving appropriate training and orientation.

Action is the service itself; it needs to have acade mic integrity, be meaningful to the student, provide for student owner. ship, have adequate supervision, and be appropriately challenging.

Reflection enables youth to think critically about their service experience. A struc. tured opportunity is provided where participants reflect through discussion, reading, writing, and production of materials.

Recognition is where youth are acknowledged for their contributions. It is also an important time for closure, particularly needed when direct service with other people is at an end. 
Importance of reflection The ultimate purpose of reflection is to get participants to think critically about their experiences. Research shows that thoughtful reflection before, during, and after the experience is the key to helping youth learn from service projects. Through structured reflection, youth make sense of what they have seen and done. Then, as they continue on the same or new service projects, they test their ide as about how the world works and about how to get things accomplished.

Reflective activities linking service experience to le arning include journals, directed writings, and structured class discussions. Lewis (1991) offers that reflecting is an ongoing process and experiences can be shared and reflected on in many creative ways:

- Reflect through speaking: group discus sion, giving speeches, interviews, debates.

- Reflect through writing: journals, news paper articles, reports, brochures, essays, cartoons, proclamations.

- Reflect through art or performance: video, posters, role plays, skits, flags, dance, scrapbooks, crafts.

Reflection questions called "Make the connection" are offered at the end of each step in the Youth Action Guide. Encourage youth to answer these questions and discuss the ir responses prior to starting the next step.
Leaders are also encouraged to keep their own journals throughout the project to reflect on and record their experiences. Part of this reflection should include answering the assessment questions found after each step in the Leader Guide. These questions are important because they help de termine if your hard work is making a difference. Keeping track of how the project goes from start to finish will help you reflect on the strengths and weaknesses of the process. Be sure to take time to think about and record your answers to the se evaluation questions.

For more information on service le arning contact the following organizations:

- Learn and Serve America

- National Service le arning Cle aringhouse

- National Youth Leadership Council

Contact information for these and many other resources can be found in the back of the Leader Guide.

\section{References}

Duckenfie ld, M., o Madden, S.g. (2000). An orientation to service le arning. in Service Learning Across the Curriculum. Lanham, $\mathcal{M D}$. University Press of $\mathcal{A m e r i c a , ~ I n c . ~}$

Learn and Serve America (2000). Online. htt $p: / /$ www.le arnandse rve.org.

Lewis, B.A. (1991). The Kid's guide to social action. Minne apolis, $\mathcal{M N}:$ Free $S$ pirit $\mathcal{P} u b$. 


\section{Leaders' $\mathcal{N o t e s}$ for the Youth Action Guide}

You will notice that most of the de tails for Give Forests a Hand activities are in the Youth Action Guide. We do not repeat that information in this Leader Guide; instead, this guide gives you an overview with sum. maries of each step and tips for leaders.

The Give Forests a Hand Youth Action Guide follows a simple sequence:

Steps 1 through 4 quickly immerse young people in exploring local forests, understanding management practices, ranking their project interests, and investigating selected topics.

Steps 5 through 8 help them choose and plan a service project in response to an identified need, kee $p$ on track with their project plan, and celebrate the ir success.

The $S$ Kills Bank provides strategies and ide as to help the group with the ir projects, such as how to brainstorm, conduct interviews, and make decisions.

The Glossary contains important terms and definitions that will aid the group's understanding of new topics.

Depending on the age and experience of participants and the amount of time available, you may adapt, combine, or eliminate several activities within a step. But be careful.. it is natural for a group to get impatient and want to "jump into action" inste ad of planning. Stress from the beginning that the group will research and carry out a service project that meets a real need and that this takes time.

\begin{tabular}{|c|l|} 
Step & \multicolumn{1}{|c|}{ Goals } \\
\hline 1 & $\begin{array}{l}\text { Learn about trees and forests. Be } \\
\text { able to explain the benefits of } \\
\text { trees and how people impact trees. }\end{array}$ \\
\hline 2 & $\begin{array}{l}\text { Discover a need for action and } \\
\text { complete a checklist. }\end{array}$ \\
\hline 3 & $\begin{array}{l}\text { Learn that forests are managed } \\
\text { for multiple-uses. Develop a forest } \\
\text { management plan. }\end{array}$ \\
\hline 4 & $\begin{array}{l}\text { Get input from natural resources } \\
\text { experts and project partners. }\end{array}$ \\
\hline 5 & $\begin{array}{l}\text { Choose a project that matches the } \\
\text { interests, sills, and resources of } \\
\text { the group. }\end{array}$ \\
\hline 6 & $\begin{array}{l}\text { Set goals, planstrategies, and } \\
\text { divide tasks. Get started! } \\
\text { experience and begin planning the } \\
\text { next one. }\end{array}$ \\
\hline Keep the project on track. Collect \\
\hline 8
\end{tabular}




\section{Step 1: Focus on forests}

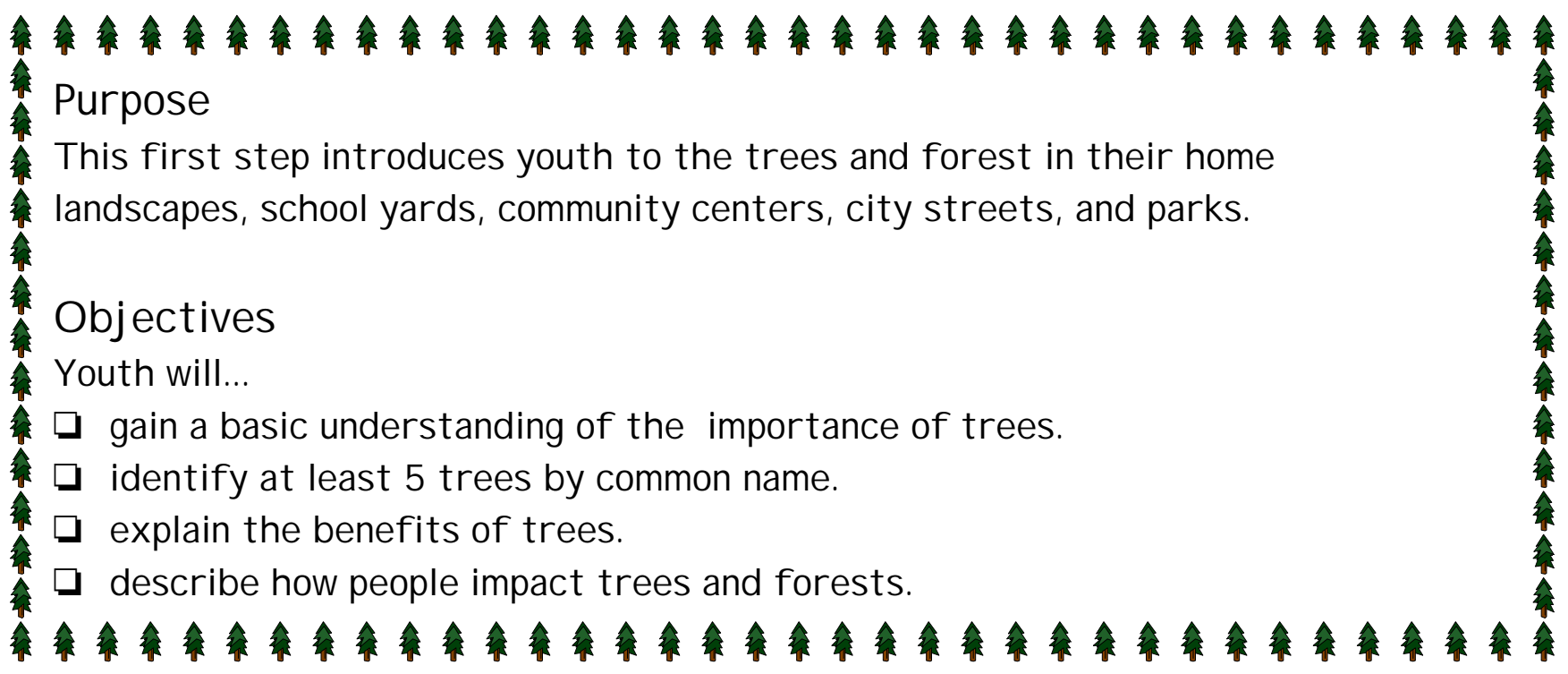

Preparation Have a Youth Action Guide for each participant or enough to share com.

fortably.

Materials needed

$\checkmark$ Maps

$\checkmark$ Me as uring tape

$\checkmark$ Flagging

$\checkmark$ Clipboard

$\checkmark$ Pencils

$\checkmark$ Tree identification guide

Take the first step Conduct a teambuilding exercise or ice breaker to help group members get to know each other. We encourage you to le ad te am-building activities throughout Give Forests a Hand. These activities foster team work and 6uild spirit. See the Activity Banksection in this guide for examples of activities.

If your group knows very little about trees and forests, supplement the Youth Action Guide with activities from other sources

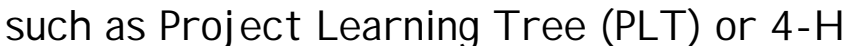
project books.

Getting started Pass out the Youth Action Guide to the group. Allow some time for them to browse through the guide.

Read through $S$ tep 1 with youth before going outside to survey your surroundings. As a group, select a nearby are a to explore and thengo outside to answer the ques. tions in the Youth Action Guide. Encourage everyone to participate by sharing duties and acknowle dge all contributions.

Feel free to use a tree identification guide to discover the types of trees in the area. You can find tree identification guides at a library or bookstore or check with your state forest agency.

Focus on forests

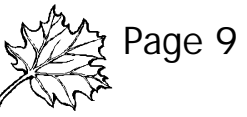


Discussion After completing parts $\mathcal{A}, \mathcal{B}$, and $\mathcal{C}$ in the Youth Action Guide, it's time for your group to discuss what they have done. Talk about what they observed, measured, and learned about the ir sur. roundings. Try to answer any questions they might have, but know that it's okay not to have all the answers. Record any lingering questions so you and your group can ask a natural resource professional in the future.

Askyouth to list reasons they think trees and forests are important; use the infor. mation in the Youth Action Guide to discuss the social, environmental, and economic benefits of trees. Use part $\mathcal{D}$, "Make the connection" to help youth reflect on the process they've just begun.

Before next time Remind youth to look over the checklists in their guides and think about the sites they would like to investigate. Explain that at the next meeting, the entire group will le arn more about the checklists and decide what site to investigate.
Related $P \mathcal{L}$ activities $\mathcal{T}$ he following ac tivities can be found in Project Learning Tree's Pre K-\& Activity Guide. Use the activities to supplement your group's intro. duction to the community forest. You can obtain a copy of the Activity Guide by attending a $\mathcal{P L T}$ educ ator workshop. Contact your state $\mathcal{P L T}$ coordinator for de tails (www.plt.org).

$$
\begin{array}{ll}
\text { \#2 } & \text { Get in } \mathcal{T} \text { ouch with } \mathcal{T} \text { rees } \\
\text { \#22 } & \text { Trees as Habitats } \\
\text { \#27 } & \text { Every Tree for Itself } \\
\text { \#30 } & \text { Three Cheers for Trees } \\
\text { \#68 } & \text { Name that Tree } \\
\text { \# 77 } & \text { Trees in Trouble }
\end{array}
$$

Activity Bank - Icebreakers

Tree gugglers Get Acquainted Choose a Leaf 
1. How many youth are involved? Approximately what are their ages?

2. Did youth know each other before starting Give Forests a Hand? $\square$ yes $\square \mathcal{N} o$

3. Approximately frow long did it take youth to comple te S tep 1?

4. Did you feel that youth had a 6 asic understanding of trees and forests before starting Step 1? $\square$ Y $\square$ es $\square \mathcal{N}$

Do youth have a better understanding of trees and forests now, after completing Step 1? $\quad \square$ yes $\square \mathcal{N}$

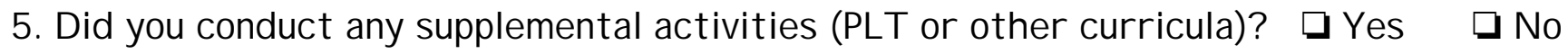

If yes, which activities did you conduct?

6. Did youth utilize Part $\mathcal{D}$, "Make the connection" to reflect on this S tep? $\square \mathcal{Y}$ s $\square \mathcal{N}$ o If yes, how well did this work?

7. Do you think that youth enjoyed the activity? $\square$ yes $\square \mathcal{N}$ o

8. Did you contact or partner with a natural resource organization or agency to felp with Step 1? $\quad \square$ yes $\square \mathcal{N}$ If yes, which agency or organization?

9. What would you do differently next time?

10. Additional reflections: 


\section{Step 2: Discover a need for action}

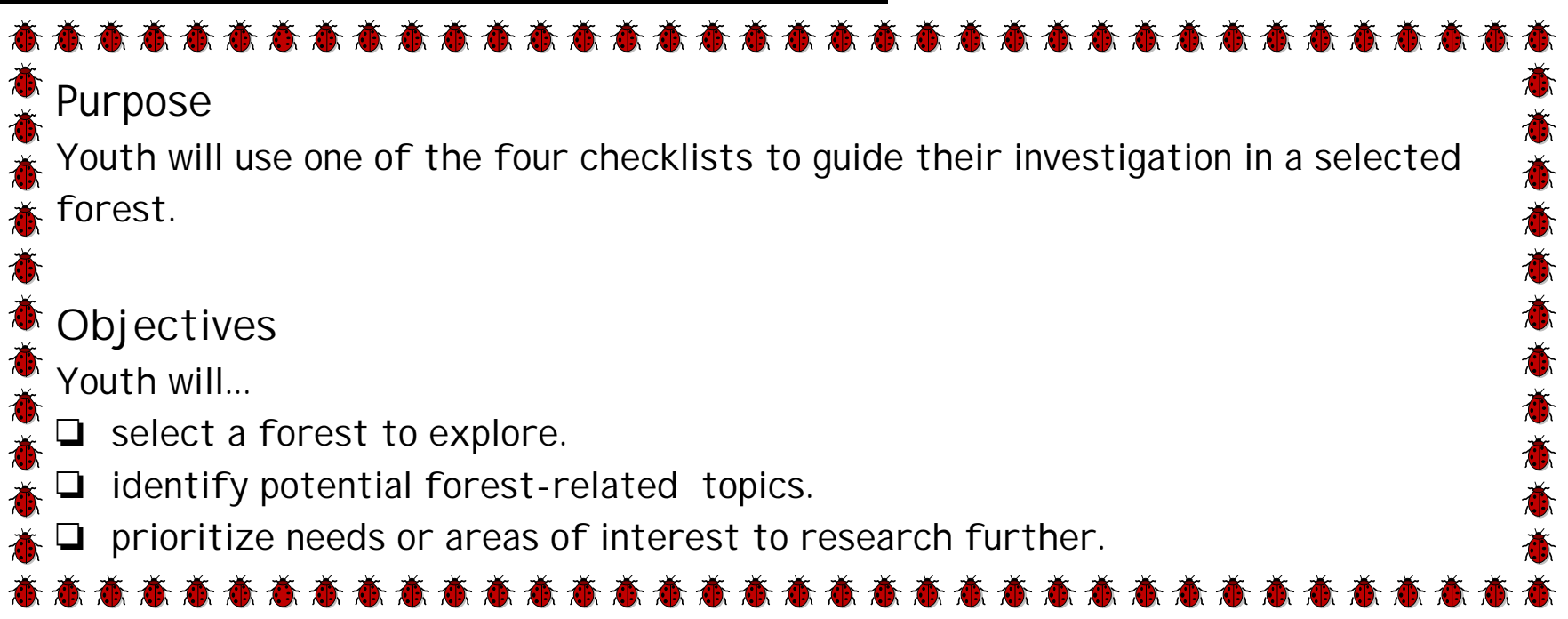

Preparation The group may need permis. sion from a landowner or agency to access the forest and complete the checklist. Ultimately, you will also need permission to conduct the project.

Materials needed

$\checkmark$ Checklists (pages 69-103) in the Youth Action Guide

$\checkmark$ Maps (See page 15 of the Youth Action Guide for information about maps)

Getting started There are four checklists included in the Youth Action Guide, each with questions focusing on a different site: Home, School, Community, and Forest. The purpose of the checklist is to guide the youth toward potential action projects. Rather than providing a list of possible projects, the checklist helps youth identify and understand problems and topics related to the ir site.

Review all four checklis ts with youth to get a feelfor the types of questions and potential issues at each site. Explain that

Discover a need for action Page 12 the checklists will be used to identify forest-related issues. Identify the types of forests near you and discuss which checklist might be appropriate for each forest.

If youth have trouble understanding the questions relating to forest management practices, you may chose to do Step 3 first, then come back to Step 2.

Help youth decide which site to use for the ir investigation. If you are limited by transportation, suggest the school or frome checklist. Youth may want to comple te investigations individually at their homes, using the frome checklist, then share the ir results as a group. If your group has an interest in working in the neighborhood, you'll use the community checklist. If you are in a camp setting, use the school or forest checklists. If a parkor forest has a lot of appeal because it is well-used or remote, confirm that this is what the group wants and use the forest checklist. 
If youth select a site other than the one they choose in $S$ tep 1 , visit the new site and investigate the trees and forests in this area. Since all group me mbers may not be familiar with the area, redo parts $\mathcal{A}$ through $C$ from $S$ tep 1. Youth may even be able to answer some of checklist questions as they investigate the area.

Completing the checklist The checklist asks questions that will likely involve additional research. Some questions need to be answered by the person in charge of the forest, such as the forest manager or city arborist. Help youth identify and contact resource people who can provide answers.

$\mathcal{N}$ ot all questions may be appropriate or relevant to the site. Explain that it is okay to skip questions that may not apply.

How much time do you have to complete the checklist?

- If you have a large group, you may want to split them into teams to ans wer questions.

- If a groupgets stuck on complicated questions, skip them and come back to the m later with an expert.

- Some questions may require infor. mation that takes time to gather; you may start the checklist at one meeting and comple te it at the next.

Is there a local organization or agency with whom you can partner?

- Encourage youth to contact local resource people for information.

- Invite a natural resource profes. sional to partner with your group.
- $\quad$ Arrange a field trip to a forest to complete the checklist.

Setting priorities The top priority issue or problem may be obvious, or it may seem that everything is important. Your job will be to help youth establish criteria for setting priorities.

Once they have completed the ir checklist, ask the m to share the ir findings. Which questions did they mark 'Very Important' or 'Tind of I mportant'?

If the group is having trouble deciding which items are more important than others - ask them, what makes something a priority issue or concern.

- Is it a priority if it affects a lot of people?

- Is it a priority if it is on public land?

- Is it a priority if it concerns plants, animals, land use, water quality, or air quality?

- Is it a priority if it will prevent future problems?

Related $\mathcal{P} \mathcal{L}$ activities $\mathcal{T}$ he following activities from $\mathcal{P} \mathcal{L}$ Pre $\mathcal{K}-\mathcal{A}$ Activity Guide will help youth explore aspects of local forests.

\# 8 The Forest of S.T.Shrew

\# 21 Loving It Too Much

\# 36 Pollution Search

\# 46 Schoolyard Safari

Activity Bank - Team Builders

Space carriers

Four-sided challenge

Discover a need for action Page 13 
1. Which checklist did youth use?
$\square$ Home
$\square$ School
Community
Forest

2. Did youth use the same site they explored in $S$ tep 1 or did they select an new site to conduct this step? Why?

3. Did youth work individually or in teams?

4. Where (or who) did youth go for help to answer the questions?

5. How many questions were rated:

Very Important

Kind of I mportant

$\mathcal{N o t}$ I mportant

List the top 3 issues that youth rated Very Important.

6. What criteria did youth use to determine the priority levelgiven to a response?

7. Approximately how long did it take to comple te S tep 2?

8. How did youth reflect on the activities in S tep 2?

9. What would you do differently next time?

10. Additional comments:

Discover a need for action 


\section{Step 3: Forests are more than trees}

I/

Purpose

Youth will learn about different types of forests and the techniques used to manage them.

当

\section{Objectives}

youth will...

$Y \square$ be able to explain management objectives for different forests.

$\Downarrow \square$ explain management techniques of nearby forests.

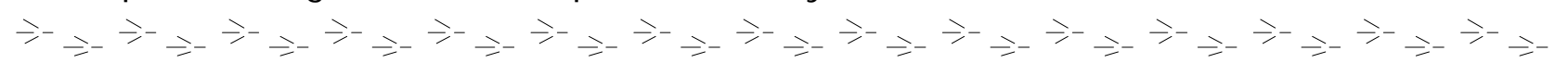

Preparation Read Forest Bits directions and decide which version to use. Copy and cut out the Forest Bits cards.

Contact your state forest agency for more information on forests in your area. If possible, visit different types of forests and make arrangements for someone to talk to the group about forest manage. ment.

Materials needed

$\checkmark$ Forest Bits cards

$\checkmark$ Forest Bits Chart

$\checkmark$ Clipboards

$\checkmark$ Paper

$\checkmark$ Pencils

Take the first step In order for youth to understand how to Give Forests a Hand, they first need to understand that not all forests are the same. Forests are managed for a variety of purposes requiring differ. ent management practices. To facilitate this learning, use the activity, Forest Bits. $\mathcal{T}$ his activity is a fun way for your group to learn about forest manage ment as well as work in cooperative groups and develop leadership skills. The instructions and materials for Forest Bits can be found on pages 18-24. After conducting the Forest Bits activity, continue with $S$ tep 3 as explained in the Youth Action Guide.

Getting started Askyouth to list different forests in their city or state. Have them select one forest, as described in the Youth Action Guide, to investigate. Encourage them to select a forest that is close enough to visit. Have youth comple te the Forest Management Practices table on page 24 in the Youth Action Guide for the forest they listed. You may need to call the forest manager, city arborist, or agency responsible for that forest and ask the m to talk with your group about the ir management practice.

Then have youth comple te the table on page 25 for the forest they investigated in Step 2. Go backthrough the checklists to see if they already have the answers.

Forests are more than trees Page 15 
Discussion Is the ir forest from $S$ tep 2 similar to or different from the forest they visited?

Related PLT Activities

\# 23 Fallen $\mathrm{Log}$

\# 24 Nature's Recyclers

\# 50400 Acre Wood

\# 69 Forest for the Trees

Activity Bank - Team Builders

To Share or Not to Share

$\log \operatorname{g} a m$

Forests are more than trees 16 
1. Were youth able to list local, state, and national Forests? $\square$ Yes $\square \mathcal{N}$

2. Were youth able to differentiate between urban and rurallocations? $\square$ yes $\square \mathcal{N} o$

3. What forest did youth visit to comple te the Forest Management Practices chart?

4. Approximately how long did it take to finish step 3 ?

5. Did you conduct any supplemental activities (PLT or other curricula)?

$\square$ Yes $\square \mathcal{N} o$

If yes, which activities did you conduct?

6. What evidence do you see that youth are developing le ade rs fip skills?

7. What would you do differently next time?

8. Additional reflections: 


\section{Forest Bits}

Choose a variation of this activity that best suits your group:

- If your group enjoys an independent challenge with little supervision-use the Emerging Leader version.

- If your group needs more guidance - use the Appointed Leader version.

Emerging Le ader

1. Divide youth into groups of six.

2. Give each group a set of six Forest Bits cards (do not include the leader card). Tell them that each card is different, 6ut each group has the same set of cards. Each group member receives one Forest Bits card from the set.

3. The objective of this activity is to answer the two questions on Card 4. No one card contains the answer but all of the cards contribute to the answer. Remind the group members that they will need to communicate the information to the group without showing anyone the ir card.

4. Give them 15-20 minutes to workthrough the task. Make sure they answer both ques tions.

5. When the groups have completed their task one member from each group will present the ir answers.

6. Summarize their presentations on forest management with an overview of why management strategies vary from place to place-Because we don't get the same thing out of every forest. It is important to understand the landowner's objec. tives before considering actions in a forest.

7. Then ask the youth what was difficult about conducting this task. Why were they not allowed to show their card to anyone? To make sure everyone was engaged in the exercise. In every group, a le ader probably emerged-how did that occur? Was it the person writing down information? The person with the question? If some groups were all male or female, ask them how this might have led to differences in the way their group functioned. Why did some groups finish faster than others?

8. Conclude by pointing out that le adership comes from many different types of opportunities, and a good leader helps all group members to become engaged, to lis. ten, and to coordinate members'contributions. A good leader is rarely the person with "the answer" because the answer comes from the group. As they continue with their project, they will need to practice good le adership skills.

Forests are more than trees 


\section{Appointed Leader}

1. Divide youth into groups of seven. Appoint one member of each group to be the leader.

2. Give each group a set of six Forest Bits cards, a Leader card, and a Forest Bits Chart. Tell them that each card is different, but each group has the same set of cards. Six group members receive one card from the set, and the leader takes the instruction card and the chart.

3. The group leader has the task directions and should comple te the chart by asking for information from the group about similarities and differences between for. ests.

4. Give them $15-20$ minutes to workthrough the task. Make sure they answer both questions.

5. When the groups have comple ted the ir task one member from each group will present their answer.

6. Summarize their presentations on forest management with an overvie w of why management strategies vary from place to place-Because we don't get the same thing out of every forest. It is important to understand the landowner's objec. tives before making plans for a forest.

7. Then ask the youth what was difficult about conducting this task. Why were they not allowed to show their card to anyone? To make sure everyone was engaged in the exercise. How did the group react to the appointed leader? What makes some groups more cooperative than others? If some groups were all male or female, ask them how this might have led to differences in the way their group functioned. Why did some groups finish faster than others?

8. Conclude by pointing out that le adership comes from many different types of op. portunities, and a good leader helps all group members to become engaged, to lis ten, and to coordinate members'contributions. A good leader is rarely the person with "the answer" because the answer comes from the group. As they continue with their project, they will need to practice good leadership skills. 

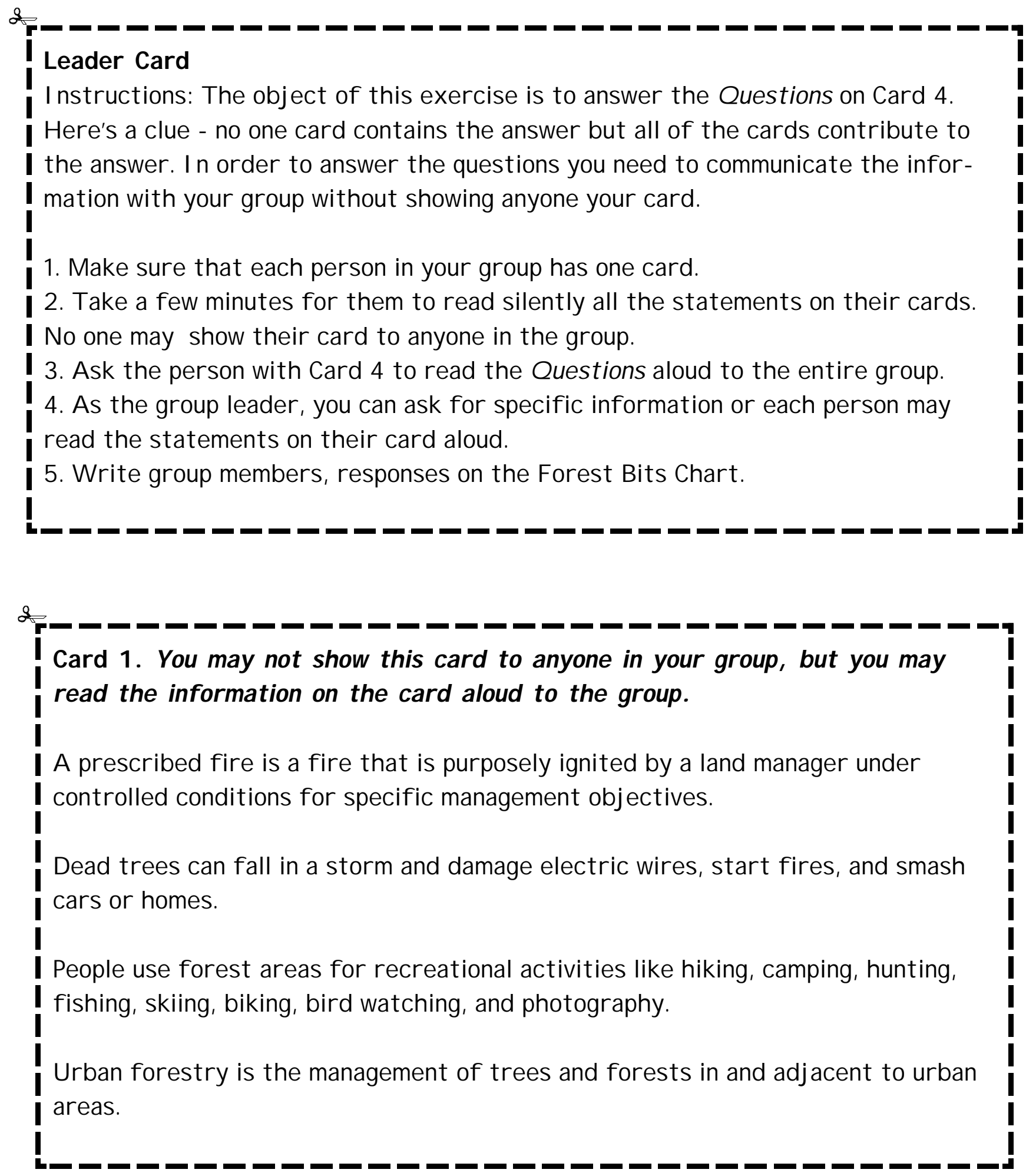


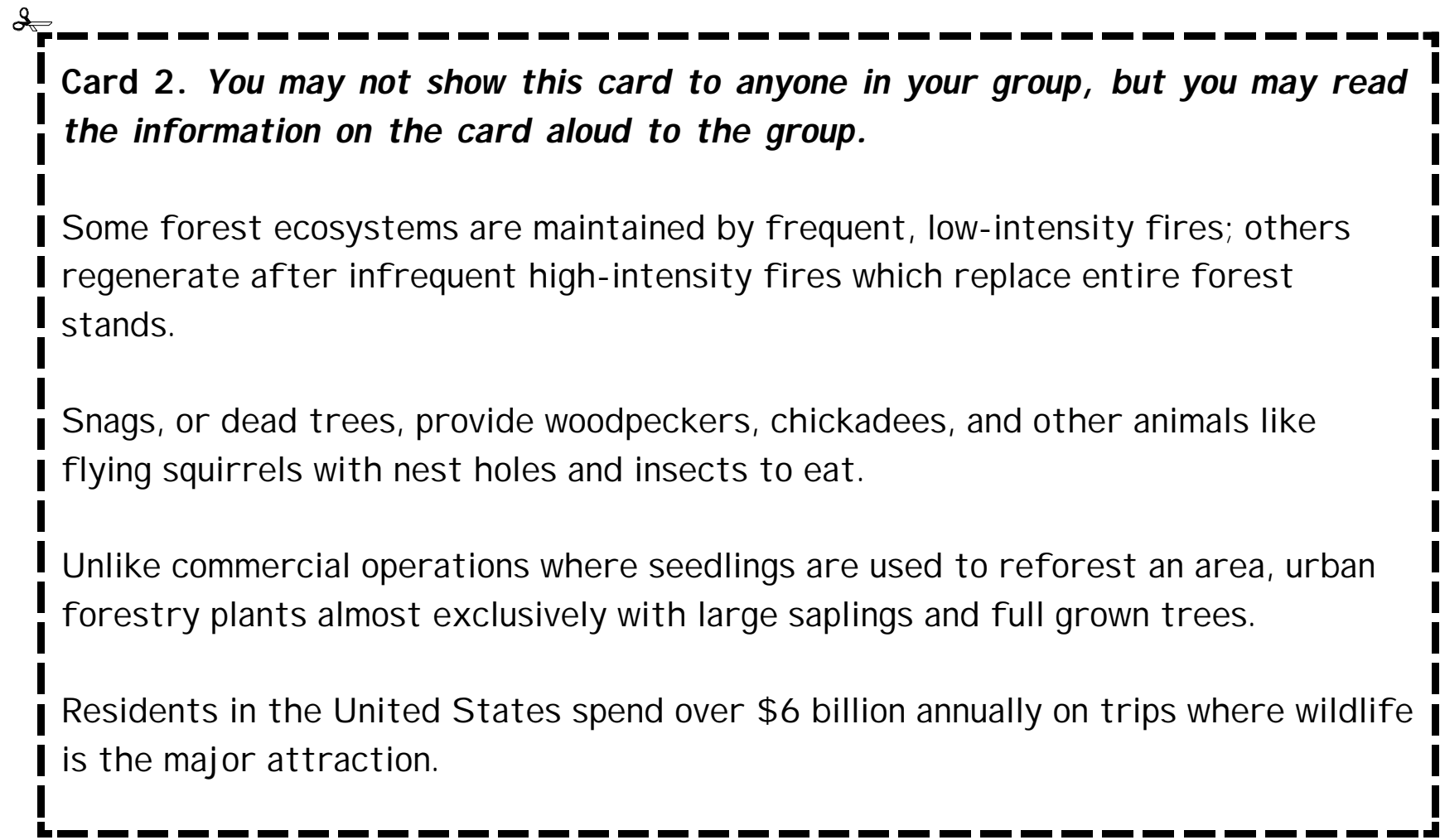

8

Card 3. You may not show this card to anyone in your group, 6ut you may read the information on the card aloud to the group.

I The 1991 wildland fires in Oakland, California, caused 26 deaths and 148 injuries.

I The fires destroyed over 3,000 structures, left over 5,000 people homeless, and resulted in $\$ 1.5$ billion in damages.

In some areas, snags are removed to kee $p$ workers safe and reduce fire hazard. I

Fallen trees decompose and replenish the soil with nutrients.

Paper comes from trees grown in plantations, from byproducts of lumber I manufacturing, or from recycled paper.

I 

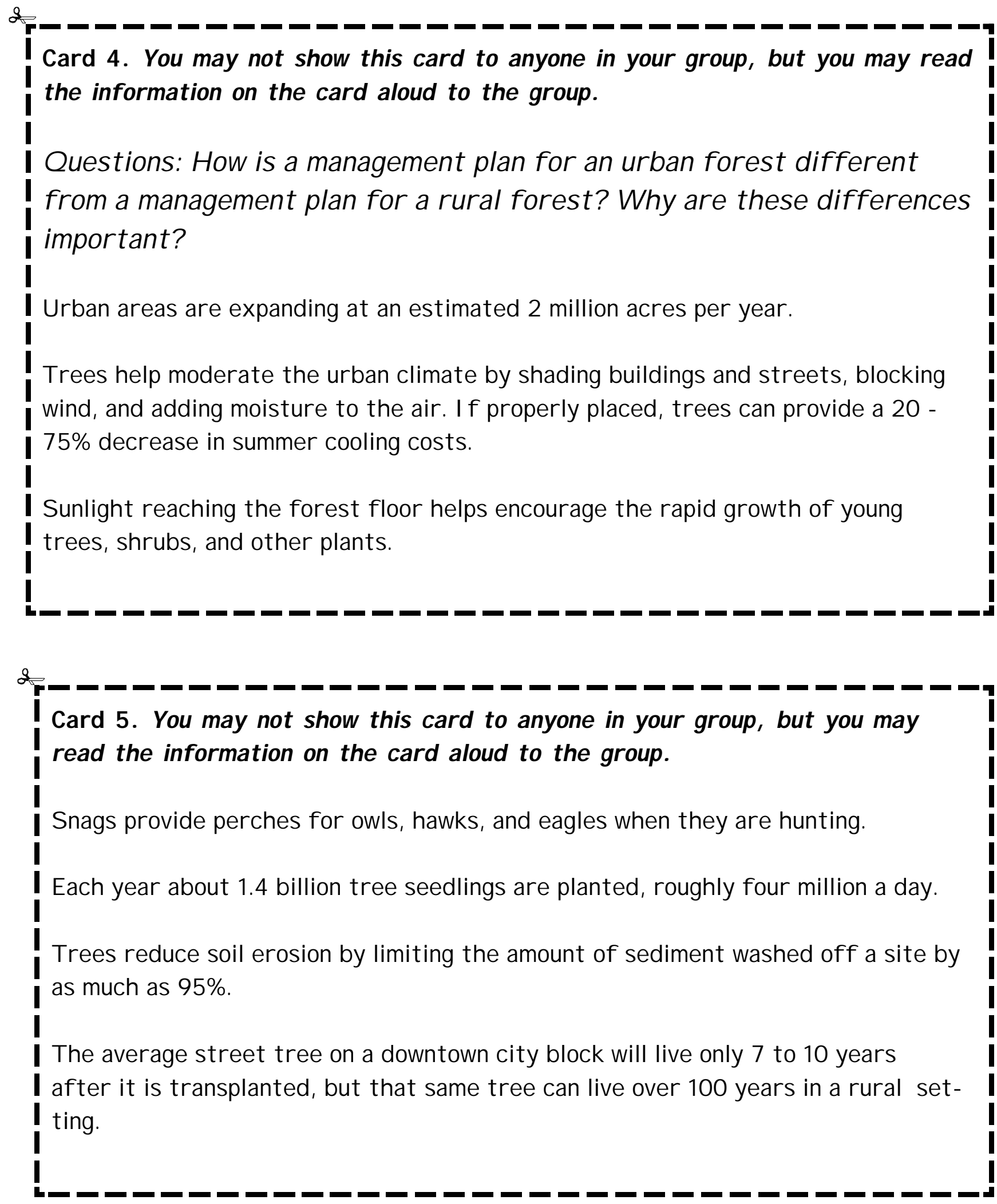


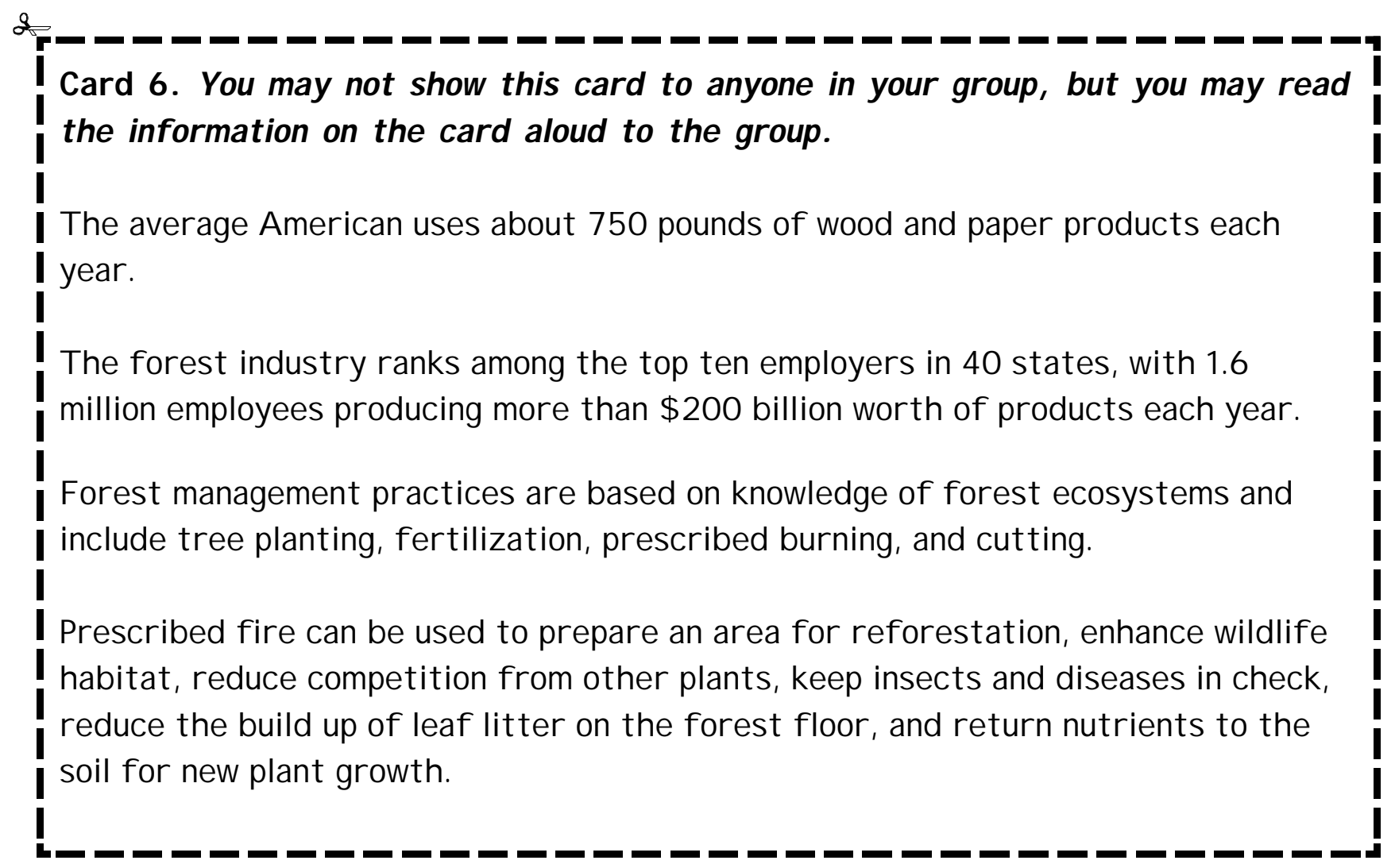




\section{Forest Bits Chart}

Urban Forest

Rural Forest

Forests are more than trees Page 24 


\section{S tep 4: Explore your priorities}

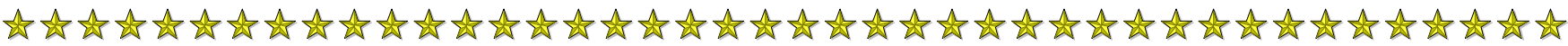
th is Purpose

Youth will identify important forest-related topics, explore these concerns in more \& detail, and prioritize possible project ideas.

究 * Objectives 齐 Youth will...

$\square$ select forest-related topics and identify important questions.

枝 gather information about forest-related topics from localexperts. 㨁 analyze the ir information.

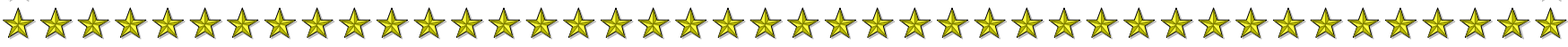

Preparation Review the results of the Checklist from $S$ tep 2 and be prepared to help the group identify two to four high priority issues for exploration if they haven't already.

Even if your group believes they are ready to start the ir service project, your job is to slow the m down. Many groups jump to conclusions or get into difficulty by not researching the issues, understanding who is involved, considering the consequences, and going through all the steps of good planning.

Good citizenship skills are based on good problem solving skills, and solving proble ms begins with understanding all aspects of the topic. These steps shouldn't take months, but they might involve several we e ks of investigation and thoughtful analys is. It may be challenging to kee $p$ their interest in a future service project, so try to point out the importance of the information they are collecting and help them see how the ir thoughtfully planned ideas are better than their first impres. sions.

Getting started Begin by reminding the group of their priority concerns from the ir checklist (S tep 2). Help the group consider how many priority topics they can reasona6 ly investigate. Be aware that limiting the group to only one concern constrains the ir future choices but more than four priorities might be difficult to manage.

For each priority, help the group ide ntify questions about the issue, the background, who is involved, and the value of potential projects that they can research. Help the m consider how to get this information. They can use local ne ws paper articles, intervie wheighbors and government officials, and talk to the landowner. Suggest they ask about potential projects that could address the priority.

Explore your priorities Page 25 
Preparing for interviews Using the $S$ kills Bank on page 63 in the Youth Action Guide, review the interviewing skills with youth. Ask the m to practice interviewing each other and you. Make sure they conduct interviews in pairs so someone can take notes. Experts may be eager to share their information, 6 ut only to a point. Interviewers who are prepared with a set of concise questions will find it easier to get good answers. Be sure to respect peoples time and busy schedules.

Discussion When the group members return with their information, lead a discussion which allows them to present the ir information and organize it into a frame work. Page 29 of the Youth Action Guide shows how a group might present and organize information they collected about their topic. This frame work helps groups see common themes and make connections among information sources. Have youth review the example and then answer the questions on page 30. Possible answers are presented in the box on the next page.

Handling controversy Many subjects for service projects are not at all controversial. Any group should find good community support for non-controversial activities. Other topics, however, may involve conflicting vie ws on how to solve problems. Your group members may discover a variety of contradictory facts and perceptions. If so, don't back away, but encourage the group to move forward with caution.
Make sure the group sees and hears view. points from different people and multiple sources. Don't try to eliminate the bias, but 6 alance it. Invite relevant organiza. tions to present their vie ws and tell their side of the story.

- $\quad \mathcal{H e l p}$ the group understand that all perspectives have some truth. Offer different scenarios and local examples where people may have a difference of opinion.

- $\quad H e l p$ the group realize that it can be difficult to lis ten to opposing views, especially if people feelstrongly about an is sue.

- $\quad$ Practice seeing multiple views. On pages 28 and 29 of this guide, you will find a brief discussion on the complexity of some environmental issues. Use these excerpts to help generate a discussion on multiple vie wpoints of these current environmental issues.

Brainstorming Part $\mathcal{D}$ is the key to selecting the right project. You can help your group brainstorm by using the Mind Map activity in the Youth Action Guide. Help the group identify as many possible activities or projects as they can. Once ideas have been listed, step back and lookfor activities that relate to one project goal. 
Related $\mathcal{P L T}$ activities

\# 19 Values on the Line

\# 33 Forest Consequences

\# 34 Who Works in this Forest

\# 57 Democracy in Action
Activity Bank - Energizers

Cle ar Cut

Running in Circles

Possible answers to the questions on page 30 in the Youth Action Guide

$\square$ What is the forest-related topic or issue? The students at Andrews Middle School are exploring potential uses of their schoolforest.

$\square$ Are there common themes among the three information sources? There is no management plan and it is unclear what the objectives or purpose of the forest are. In addition, those involved have different opinions about how the forest should be managed.

$\square$ Who else could the students contact for information? Other neighbors, teachers, and students at the school, school board, city planners, and community $\square$ members.

What problems might occur if the students go through with the ir project with. out talking with the neighbors? Some neighbors may not like what the students do, they may get upset, and could put an end to the action project. Even though the neighbors may not own the forest, they still have a stake in its management. Everyone who has an interest in the topic needs to be included in the discussion.

$\square$ Can you think of anyone else who might object to the students developing a plan for the schoolforest? Besides the neighbors, other people may also be concerned for a variety of reasons. Local nature groups may want the forest to be left alone. School board members may want to build new classrooms on the site.

$\square$ List 5 project ideas that the students could do based on the information collected. The possibilities are limited only by time and imagination! Some examples are: developing a working forest, create an information campaign on the impor. tance of urban forests, construct nature trails throughout the forest, set up educational displays about forest ecology, and conduct a tree inventory of the forest. 


\section{Is it good or bad...or both?}

Many environmental issues are difficult to resolve because the issues are complex and depend on the local context. Solutions that are believed to be helpful may be harmful in other parts of the country. Knowing what to do about some environmental problems can be tricky and the first step is to find out more about your localcontext for this issue. For example, although washing cloth diapers instead of using disposables makes sense where landfills are full but in are as where water supplies are limited it may not be the best answer.

Recycling Paper: Reducing waste, using resources wisely, and recycling resources are good basic rules to live by. Although recycling paper helps save landfill space, depending on the context, paper recycling may not be good for forests. For example, an effective paper recycling system should reduce the need for cutting trees for pulp. If that means enormous Sitka spruce trees are not chipped, most people would see this as a good thing. If that means trees are allowed to growbigger for a saw timber market, that, too would keep the forest intact for another $10-20$ years. But if that means a tree farmer can't sell pulp logs to pay his daughter's college tuition, he may decide to sell his land to a developer. Pavement is not good for any forest.

$\mathcal{N}$ ative Plants: Trees and other plants that evolved in an ecosystem play an important role in the health of that system. They also tend to provide wildlife and insects with food and shelter. In many areas, planting native species is encouraged to restore func. tional ecosystems. But there is also a role for non-native plants, especially in botanical gardens, arboretums, and urban areas that want to showcase a variety of trees. In some instances, native trees no longer grow well in the urban forest because the urban areas has been altered so dramatically. Non-native trees may grow better and may be the best option. Explore the management objectives for the area and the desire of citizens.

Invasive Plants: Sometimes the difference between a "good" plant and a "bad" plant is where it is located. Some weeds are considered invasive because they have the potential to take over natural are as and change the ecosystem. But should we get rid of all weeds, or do they have a role to play in the ecosystem? Contact your local natural are a manag. ers to understand which plants are invasive and damaging to the region. Find out how they are spread and what the source is. Perhaps you can help reduce the problem. 
Cle arcutting: If we want to use trees for pulp and timber, we need to cut the m down. What are the ways that trees are harvested in your area? There are economic advantages to cutting all the trees at once, 6ut there are also disadvantages, particularly if rain washes soil down a slope. Open patches allow foresters to replant the forest with species that grow quickly in full sunlight. What kinds of trees are used to reforest local areas that have been harvested? What are the characteristics of these trees that make them idealfor the site? The sunlight also encourages shrubs and other plants to grow, which often bring deer, birds, and insects to these cleared areas. Make sure youknow how a harvest plan fits an overall forest and wild life manage ment strategy.

Fire: Many of our forest ecosystems depend on fire to maintain a healthy ecosystem. If fire is excluded, the dead branches and thick undergrowth may create a situation where future fires are especially severe. Because more people live in and around forest areas, it has become important to protect their homes and put out fires. Fire that is out of control can be very dangerous. Can we have people in the forest and fire? What alternatives work in your are a for reducing the fuel in a forest?

Wildlife: Pe ople enjoy seeing wildlife in a forest and want to make sure their habitat is protected. But some wild animals can become a nuisance to the people who live near a forest. Deer and beaver may eat expensive landscape trees in yards, rather than those in the forest openings and along the stream. Geese have become a nuisance on many golf courses and parks. How can we balance our needs with wildlife's needs? Learn about local wildlife population dynamics if you tackle a wildlife habitat project. 
1. Do you feel like your group was prepared and knew enough to start a project? $\square$ Yes $\square \mathcal{N} o$

Why or why not?

2. How did you encourage youth to collect more information?

3. How did the youth feel about conducting intervie ws?

4. Who was intervie we d?

5. Are the youth investigating a controversial issue? $\quad \square$ yes $\square \mathcal{N} o$

6. What would you do differently next time?

7. Additional reflections:

Explore your priorities 


\section{Step 5: Choose a service project}

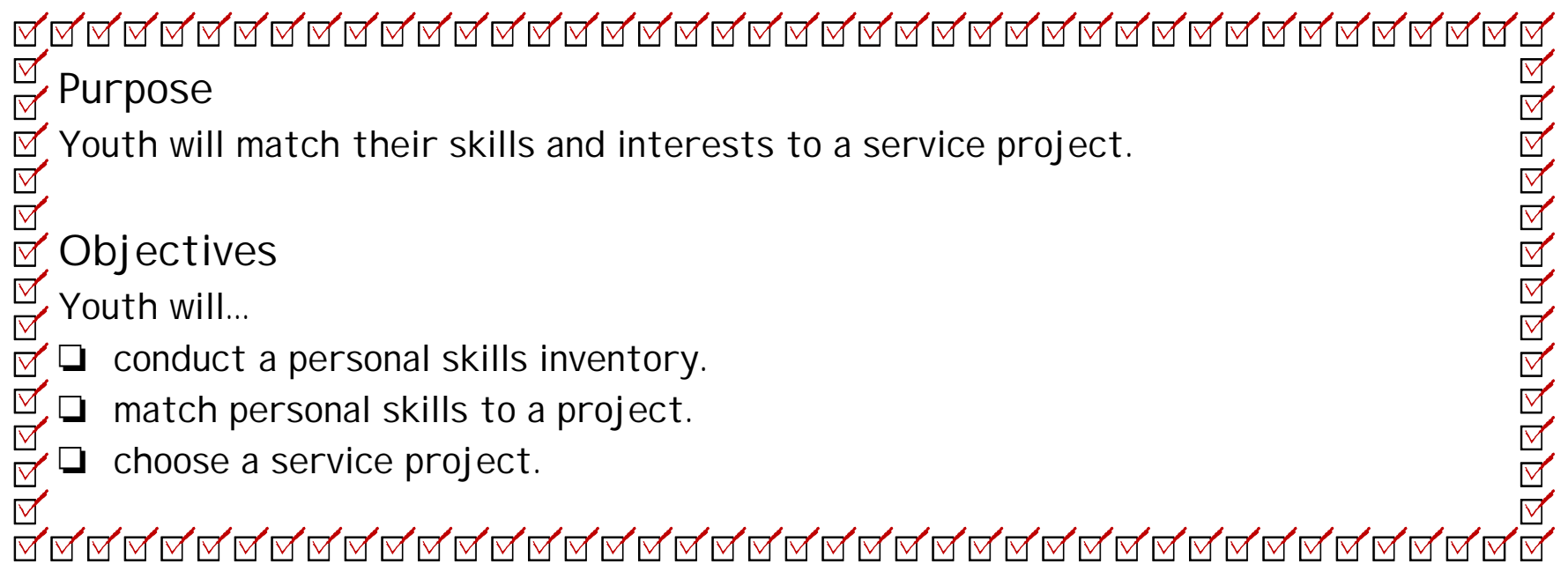

Pre paration Remind group me mbers to bring their mind maps, notes, and journal from previous sessions.

Getting started $\mathcal{T}$ his is a very exciting stage for your group. Your role is crucial in ensuring that your group chooses a realis. tic project in terms of their skills, resources, and interests. Time, in this case, should also be seen as an important resource. Starting with a longer list of possible projects, narrowing it down, and ending up with one project provides for a good analytical and decision making process.

S tep 5 begins by asking youth to reflect on what they are good at doing. In the excite. ment of a group meeting, young people can generate all sorts of ideas about what they could do. If their ideas don't match their skills or interests, the project may languish or fail. If they first remember their skills and what they like to do, the group is more likely to generate a project that matches their abilities. As the pro. ject progresses, be sure to point out any new skills and interests youth develop. Have them add these to the ir inventory.

Have the group match their skills and interests with the ideas brainstormed earlier to determine which project ide a best fits the group. Your group may all agree on one idea but if there are differ. ing opinions on which project is best, a decision needs to be made. The Youth Action Guide suggests several ways to help make this decision. You may suggest gath. ering more information to understand the advantages and disadvantages of each project ide a and help the decision process. Perhaps another session of interviews and phone calls would be good.

Project boxes The next step is for youth to consolidate all the ir information into one or two project boxes. Have youth fill out a project idea box for each project identified in part $\mathcal{B}$ of the Youth Action Guide. First, have youth come up with a

Choose a service project Page 31 
catchy name for each project. A naming contest will get youth exited about their project. Make sure youth write a goal statement for each project; this will help youth create a clearer picture what they intend to accomplish. Go back to the mind map in $S$ tep 4 and fill in the project activities that were listed for each idea; youth may want to add to this list.

Hurraf! Your group has a project! Once the project ideas are narrowed down to one, have youth climb the Decision Ladder on pages 42 and 43 in the ir Youth Action Guide to see if they are ready to begin the ir project plan. For some groups, this will be a process of confirming what they already know. For others it might suggest additional information that would be help. ful. If the question is irrelevant to the project idea, encourage the group to step up to a more meaningfulquestion.

Finding time and transportation Service projects take time. Help the group be realis tic about how much time they have and when it occurs. Parents, volunteers, and partner organizations may be willing to help supervise service work. School-based programs can link service le arning to the curriculum so that class time may be used to complete service projects.

Unless your project occurs in your backyard or neighborfiood, your service project is likely to involve transportation as well. Public transit, school buses, bicycles, and partners may be available for moving the group to the project site. Be creative!

Choose a service project
Involving families Parents and guardians can provide welcome supervision and/or expertise. This is also important because children whose families are involved in community issues are far more likely to stay involved the mselves. Additional adults may help 1) find funding, 2) provide trans. portation, 3) help the group plan, organize information, and identify a project, 4) checkout possible service sites, 5) present background information or training, 6) evaluate the project, and 7) helporganize a celebration.

It is important to clearly explain roles and responsibilities to parents or guardians. Make sure they understand your role.. and its limitations -. as project leader. Encourage them to provide suggestions along the way. Whatever their role, parents or guardians must be kept informed about what their youngsters are doing. A brief note can acknowle dge the ir contributions and avoid misunderstandings.

Funding Funding nee ds will vary from project to project. Try local sources: individuals; civic groups; 6 usinesses; community organizations; government agencies; and community, corporate, or nonprofit foundations. Use your partner organization for ide as and in-kind donations such as tools, seedlings, paint, or use of veficles or copiers. Service le arning projects in many states have funds (contact your state education agency), as well as state 4-H H offices. Your state $\mathcal{P L T}$ office may have more information about Green Works!, a funding opportunity that provides money for youth projects. 
Related PLT Activities

\# 54 I'd Like to Visit a Place Where

\# 56 We Can Work It Out

\# 89 Trees for Many Re asons
Activity Bank - Decision Makers

Add It up

Decision Tree

Step 5: Choose a service project

1. How easy was it to reach agree ment on a service project?

2. Are all group me mbers in favor of the decision?

$\square$ Yes $\square \mathcal{N} o$

3. Is everyone contributing a personal skill to the process? $\square$ yes $\square \mathcal{N o}$

4. How helpful was it to use the Decision Ladder found in the Youth Action Guide?

5. What would you do differently the next time?

6. Additional reflections: 


\section{Step 6: Project plan}

re

Purpose

Youth will create a plan of action for their service project.

(3)

8

Objectives

Youth will...

$\square$ develop a de tailed project plan, including individual tasks, timeline, and safe ty plan.

$\square$ organize project ideas into specific tasks and assign individual or group.

$\square$ begin workon their service projects.

7

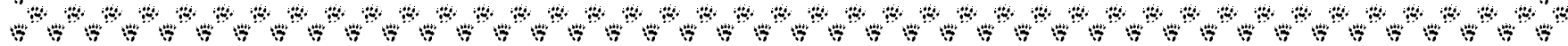

Pre paration Arrange for partners and others to review the group's plan. Review notes and materials from earlier exercises.

Getting started It is important to help young people set goals that are challenging yet achievable given the available time and resources. Help youth identify tasks or activities needed to accomplish the project's goals. Assist youth in prioritizing tasks and ident ifying individuals responsible for completing each task. The example on pages 47 and 48 of the Youth Action Guide will help the group work through the process of organizing tasks. Prompt the group by asking, "What needs to be done in order to accomplish this task?", "Are any of the tasks similar?", "What types of things do you need to accomplish each task?", and "Who else needs to be involved in the project?"

When the project plan is completed, every taskshould have a deadline and a person responsible for it. Remember, it's okay to change the plan later, but it is important to make a plan so everyone knows their duties and deadlines.

Safety Plan Identify risks your group might encounter in doing the project. Young people are more likely to be have safely if they have helped to identify risks, set the rules, and develop a plan to deal with emergencies.

What are the general risks?

Weather

Traffic

Crime

Poisonous plants

Are there project-specific risks?

Trash with sharp edges

Hazardous substances

Dead branches on a tree

Insect or snake bites 
What can be done to reduce risks?

$\square \quad$ Work with a buddy at all times

$\square \quad$ Re ad and follow ins tructions

$\square \quad$ Wear proper clothing

$\square \quad$ Drinkplenty of water

$\square \quad G e t$ training to use equipment

口 --- - - - - - - - - - - - - - - - - -

Establish emergency procedures and make

sure everyone knows them.

$\square \quad$ Post 911, hospital, and other

emergency phone numbers.

$\square \quad$ Have a first aid kit, ve ficle, and

driver available when working on

projects.

Related $\mathcal{P L T}$ Activities

\# 54 I'd Like to Visit a Place Where

\# 90 The Native Way

\# 91 In the Good Old Days

Activity Bank - Energizers

Tree $\mathcal{T}$ wisters

One at a Time 
1. Did youth find it easy/difficult to break the bigger project ide a into smaller tasks?

2. What made it easy or difficult for youth to create a plan of action?

3. Did youth create realis tic tasks given their timeline? $\quad \square$ yes $\square \mathcal{N}$

4. How is group communic ation and le adersfip evolving?

5. Are youth sharing the project responsibilities evenly or are a few group members taking over?

6. Did you conduct any supplemental activities (PLT or other curricula)?

$\square$ yes $\square \mathcal{N} o$

If yes, which activities did you conduct?

7. What would you do differently next time?

8. Additional reflections: 


\section{Step 7: Keep on track}

\section{Purpose}

Youth will successfully comple te a forest-related service project.

Objectives

Youth will

Keep a record of project accomplishments.

$\square$ evaluate their projects using a variety of measurement.

$\square$ workthrough or overcome problems that hinder success.

1

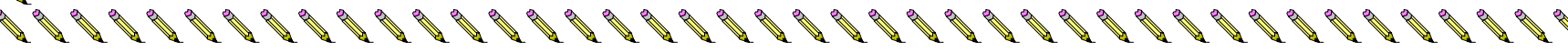

Pre paration Review the Project Plan as needed. Closely watch to see where the group runs into trouble: use information in the Skills Bank to build the group's skills.

Getting started Hold regular meetings to check on the status of assigned tasks. Ulse the Project Plan as a guide to check that tasks are being completed thoroughly and on time, but remember it is a flexible guide and not a rule book. Ulse these regular meeting times to discuss problems and alternative actions. It is important that youth continue to work cooperatively and communicate with each other; team building exercises may be especially appropriate to begin each meeting.

To help keep your group on track and show that the project has made an impact, youth will need to collect data on their project. Review the types of information they might collect on page 55 of the Youth Action Guide then 6rainstorm the types of data they could collect and how they will collect it.
Leader evaluation and program improvement Evaluation does not need to be expensive or involve specialized exper. tise. By completing the Leader Reflection questions at the end of each step, you alre ady have a good start in evaluating your program. You may also have already collected other data that will help the effectiveness of your program, like participation and attendance records, individual project notebooks, partner feedback, or letters of support.

You can always ask for feedbackfrom participants, partners, and any organizations receiving services. Some useful questions to ask are:

- Did the project meet your needs?

- What would you like to see changed?

- What impact did the project have on you, your organization, and the community?

Activity Bank - Energizer

Tree Twisters

One at a Time

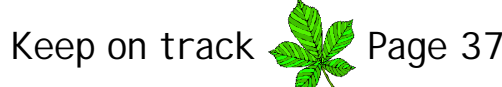


1. Do you feel that youth followed the ir project plan and timeline throughout the project?

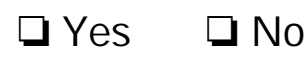

2. How did youth revise the ir project plan or timeline?

3. How did youth measure success?

4. Did youth run into problems or roadblocks while doing the project? $\square$ yes $\square \mathcal{N}$ o

If yes, how did these get resolved?

5. Did youth hold regular meetings to discuss ongoing project activities? How many were needed?

6. What other agencies or organizations are involved? What contributions or actions have they offered toward the success of the project?

7. What do you wish you knew ahe ad of time about this project?

8. Additional reflections:

Ke e p on track Page 38 


\section{Step 8: Celebrate success}

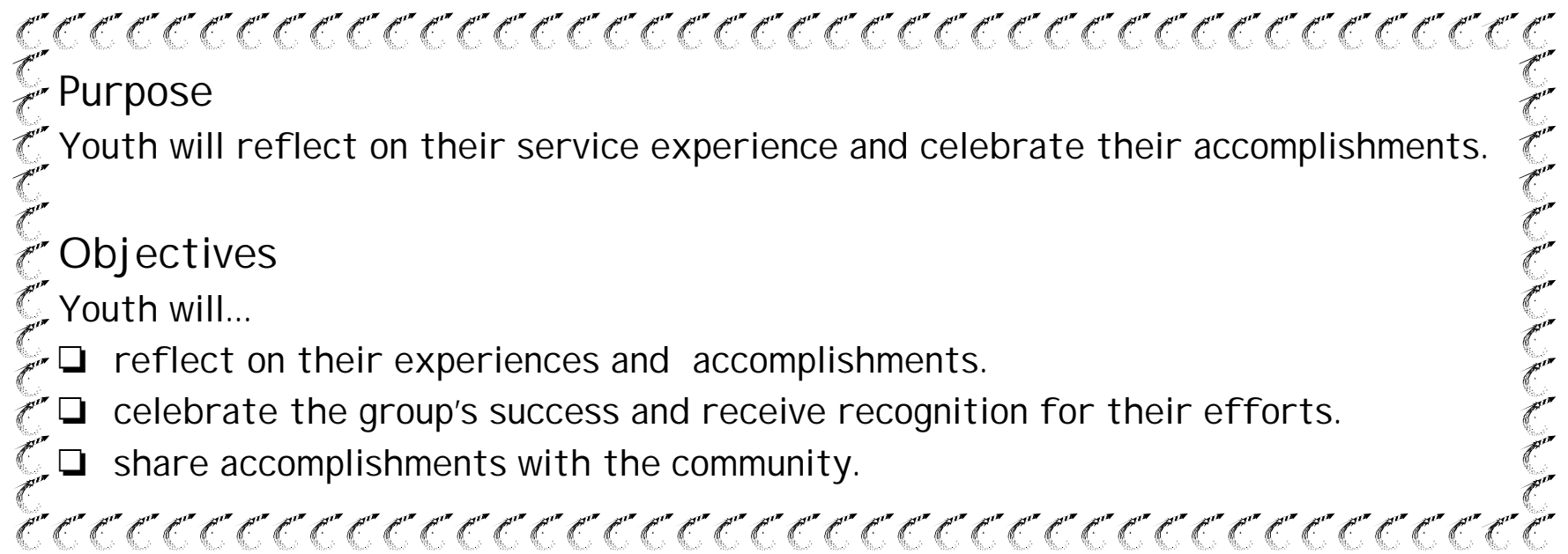

Materials needed

\section{$\checkmark$ Celebration supplies}

Getting started Help the group reflect on their accomplishments. Whatever the level of success, state your pride in the ir com. mitment and effort.

Reflection $\mathcal{T}$ is is an important time to reflect on all that has happened over the past weeks and months. Prompt youth to share their experiences using the ques. tions on pages 59 and 60 of the Youth Action Guide. Share your experiences with the $m$ as their leader and encourage the m to contribute their thoughts, feelings, and experiences.

Once youth have reflected about the project process, help them figure out ways to communicate what they have done to oth. ers. Help youth write press releases and send them to newspaper, radio, and $\mathcal{T} \mathcal{V}$ stations. Your youth may want to put a presentation together for the student body or the county commission.
Cele brate! Cele brations can strengthen a person's sense of self-worth, unify a group, and 6 ring closure to a project. Local recognition cele brations can acknowle dge part. ners and other supporters as well as group members'commitment to the ir communities and the environment.

Organize a cele bration that is meaningful to those involved in the project. It can be as elaborate as a banquet, as fun as a pizza party, or as simple as frolding a ceremony at a regular group meeting. Partners and supporters will likely appreciate publicity, and feel moved by genuine expressions of appreciation from youth. Pictures, $s$ kits, videos, and public testimonies by youth can be very influe ntial. 
Parents or volunteers might like to organ-

ize a party for the group, or the group may

want to organize the ir own. Partners may

also be willing to provide recognition, such

as by giving award certificates to group

me mbers. You can de velop your own cer.

tificate for your group me mbers.

The next steps The members of your

group have le arned valuable lessons in good

ste wardship; as you tackle new projects,

they will continue to le arn and grow as

individuals and as a group.

Related $P \mathcal{L}$ Activities
\# 59 Power of Print
\# 60 Publicize It 
1. Do you think that your project met an important school or community need? $\square$ yes $\square \mathcal{N o}$

If yes, how your project met an important need?

2. What did you think youth learned as a result of their service experience?

3. Do you feel that you were successful in guiding youth to make the ir own decisions? $\square$ yes $\square \mathcal{N o}$

4. How closely did you follow the steps in the Youth Action Guide?

5. What would you do differently next time?

6. What will youremember about this experience five years from now?

7. Additional reflections: 


\section{Activity Bank}

The following activities will help you foster skills among your group and create a be ter flow for group meetings. These activities are also meant to be fun! Take time to talk after each activity using the suggested questions or your own.

The following activities were adapted from The Encyclopedia of Games for Trainers (Kirby, A. 1992, Amherst, MA: HRD Press): Choose a Le af, Four-Sided Challe nge, To Share or $\mathcal{N}$ ot to Share, Stranded, Add It Ulp, Clearcut, Tree Twisters, Running in Circles, and $O$ ne at a Time.

\section{Ice breakers}

If the members of your group do not knoweach other, these activities will facilitate introductions and help members get to know one another. Even if the members already knoweach other, these activities are still good ways to start a meeting and to learn more about each member.

\section{Icebreaker 1 - Tree gugglers}

Procedure: Stand in a circle. Askeach person to think of a tree that starts with the same letter as their first name. If youth are not able to think of different tree names, ask the group for help. Have each person introduce themselves by the ir first name and the ir tree name, for example, "I uanita g uniper" and "Alex Alder."

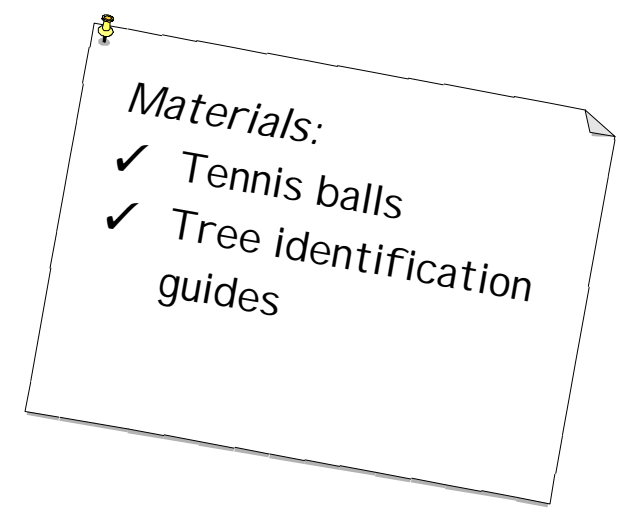

Begin by saying the person's tree name and bouncing the ball to that person. That player then bounces the ball to another player, calling out his or her tree name. Continue until everyone has had the ball at least once. Now speed up. When this gets easy, add one or two more balls.

Discussion questions:

Who can name every person in the group?

Why did you choose the tree names you did?

Do you know what all these trees look like? Where can you find that tree?

Extended activity: If youth are not familiar with their type of tree, have each person look up their tree and share the description with the group.

Activity Bank 42 
Icebreaker 2 - Get Acquainted

Procedure: Place the strips into a hat. Have youth pick one strip from the hat and find a partner. Each person has one minute to discuss the assignment on the strip of paper while their partner listens. Reverse roles for another minute. Participants then exchange slips and find ne w partners.

\section{Materials:}

$\checkmark$ Copy of the table below and cut it into strips. If you have more than ten youth, make several copies or create additional strips.

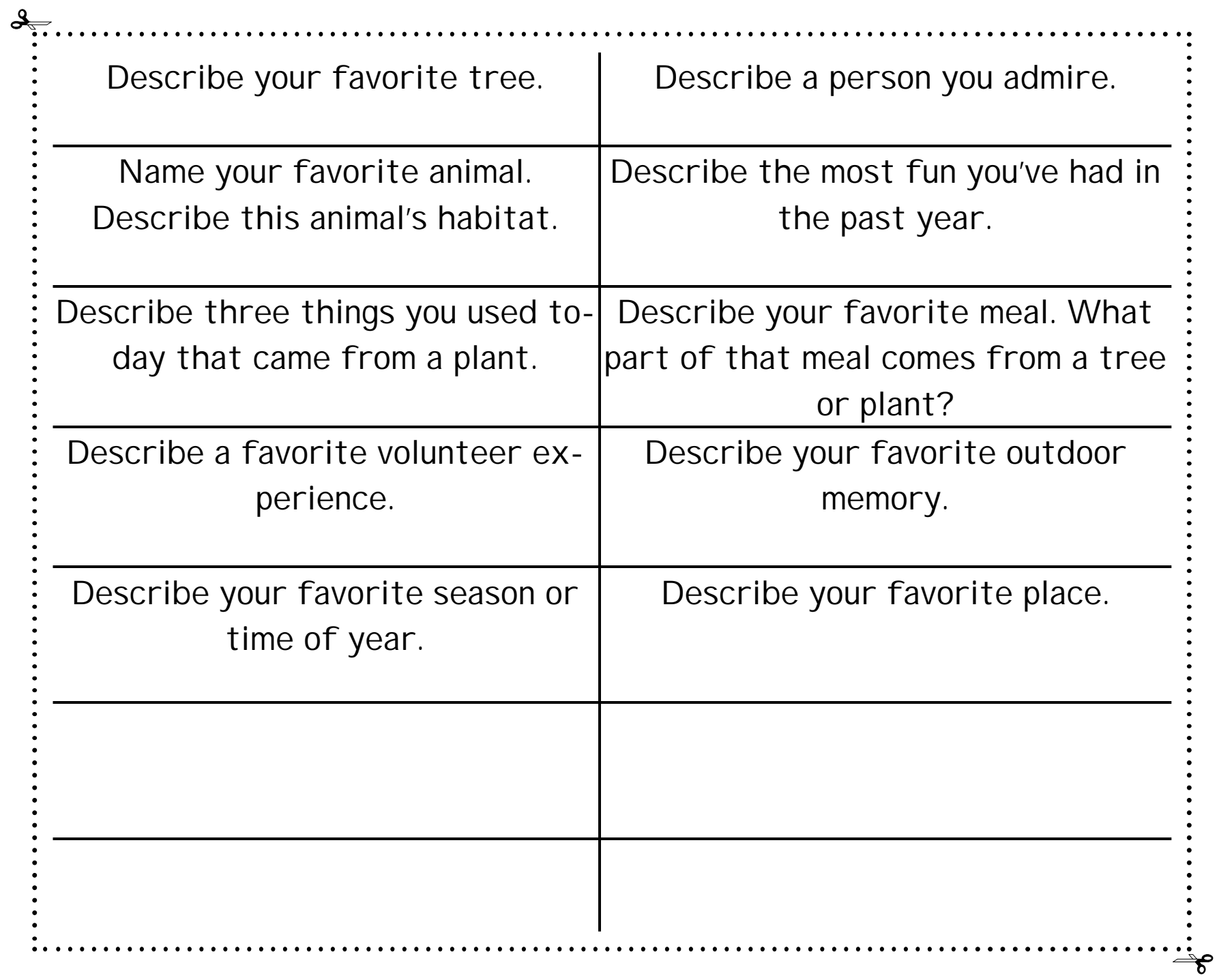

Activity Bank 
Icebreaker 3 . Choose a Leaf

Procedure: Spread the leaves out on the floor or a table. Invite group members to examine the leaves and to select a le af with which they can identify. Form group members in a circle and have them take turns introducing themselves, showing the ir chosen leaf, and explaining why they chose it.

Discussion Questions:

Who knows what type of tree his/her le af came from?

If you don't know what tree a le af came from, how could you find out? How are all the leaves similar? How are they different?

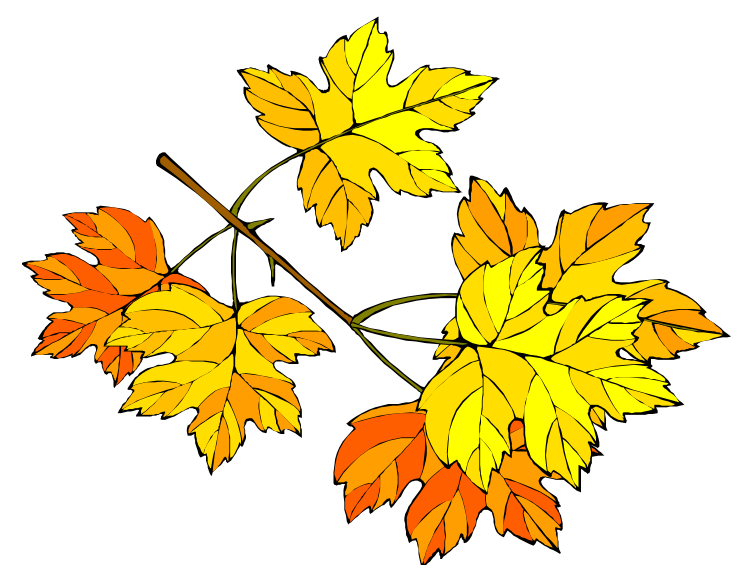
of your group.
Materials:

$\checkmark$ A variety of tree leaves. At le ast one for each me mbers

Tree identification guides. 


\section{Te am Builders}

Team building activities teach cooperation, negotiation, and the importance of both verbal and non-verbalcommunication.

Te am Builder 1 - Space Carriers

Procedure: You need to prepare carriers in advance, one for each group of $8-10$ people. Tie 4 or 5 three. foot lengths of strings to a rubber band (four for eight people, five for ten).

Break into groups of $8-10$. Explain that cooperation and communication is crucial to the success of any group project and youth must use both just to move a single cup of water from one point to another. Each group forms a circle and everyone picks a partner. Blindfold one partner from each pair, and hand each blindfolded person one of the strings.

Set a paper cup of water on the floor in the center of each group. Tell groups they have to use the carrier to pick up the cup, lift it off the ground without spilling any water and move it 20 feet to a designated spot. The blindfolded partner is the only one allowed to touch the string. The non-6lindfolded partner can talk only to their blindfolded partner, and not to any other pairs.

Give the groups five minutes to work. Do not tell the m how to do the task. If they spill a little, say, "Oops! Careful," but keepgoing. If the cup tips over, have them start again; or stop and talk depending on time and frustration levels. When one group succeeds or time runs out, take off blindfolds and discuss. Now, try again, letting pairs talk to each other or with one person directing the four blindfolded people.

When partic ipants pull on all strings equally, they can stretch the rubber band large enough to fit over the cup. When they slowly rele ase the strings, the rubber band fits snugly around the cup so it can be lifted. 
Discussion Questions:

Was the task difficult? Why? Why not?

Was is harder when verbal communication was not allowed? How did you communicate?

How can we increase communication on our project?

Team Builder 2 - Four-Sided Challenge

Procedure: Before beginning this activity, make a copy of the five squares (see patterns on next page) so that each group will have one set. Cut the squares into the pieces as marked. Place the pieces of each square into similarly marked envelopes. Each group will have five envelopes containing the parts for the five different squares.

Divide youth into groups of five. Explain that each group will receive five envelopes containing the needed parts to make five squares. Each square will be the same size. The group must assemble the five squares from the pieces provided.

The rules are (it may help to right the rules on a board or flipchart):

$\mathcal{N o}$ group member may have more than six pieces in front of them at a time. There can be no verbal communication or sign language.

You cannot take pieces from another person and you cannot ask for another person's piece to be given to you.

Ans wer any questions that might arise and then allow the groups to go to work and continue until all groups comple te the task.

Discussion questions:

How did you communicate with each other?

How did you work as a te am or did you work individually?

How did your group me mbers help? How did they hamper your efforts?

Did your group have a leader? How did this work?
Materials:

copy the patterns for the activity and cut into pieces. corresponding envelopes, $\checkmark$ Place the pieces in marked a through e. 
Pattern pieces for the Four-sided Challenge

Cut construction paper into the following pieces and place into envelops (a-e) according to the letter on each piece.
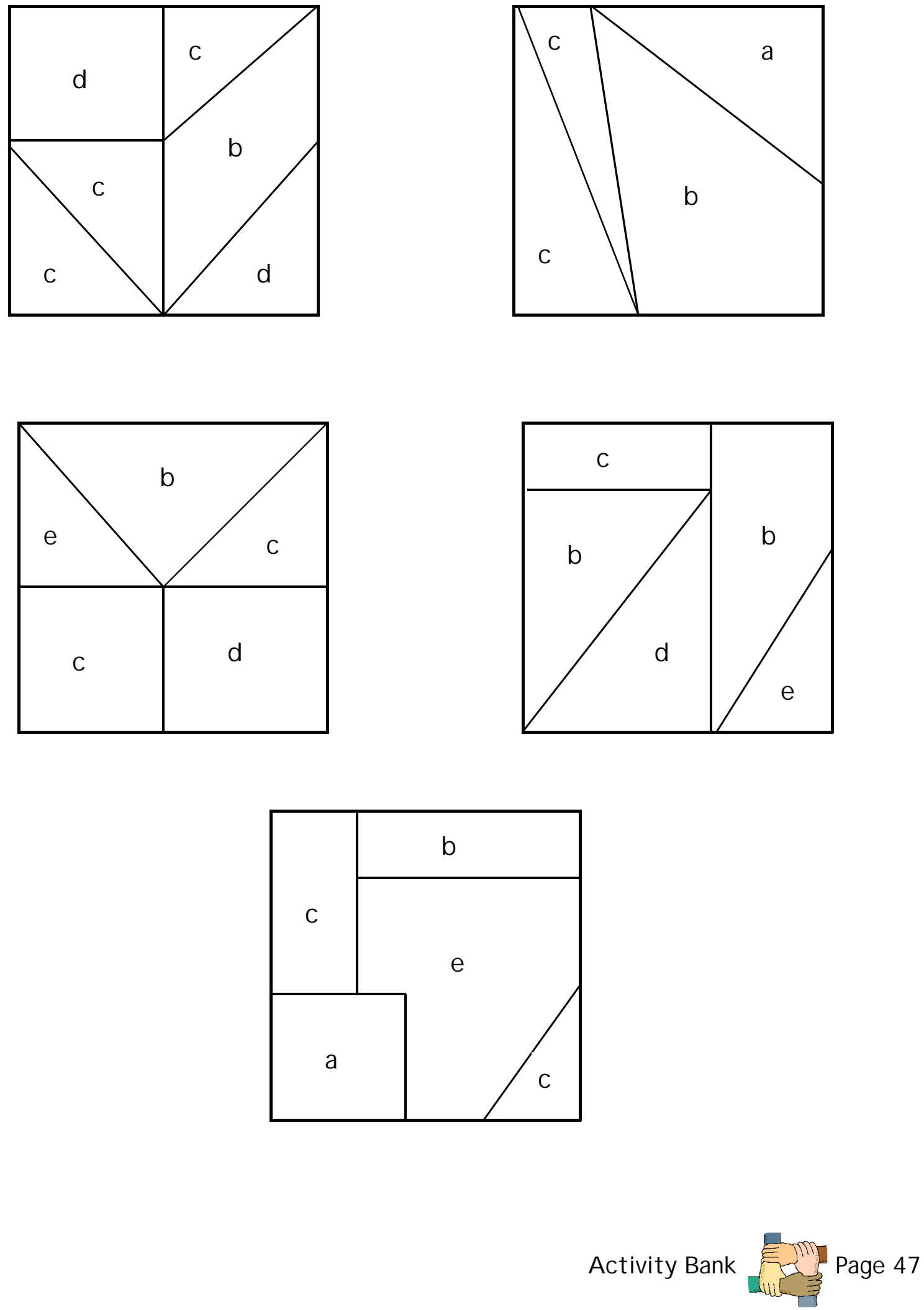
Te am Builder 3 - Log I am

Procedure: Tape seven pieces of paper to the floor in a straight line, as illus trated 6 e low.

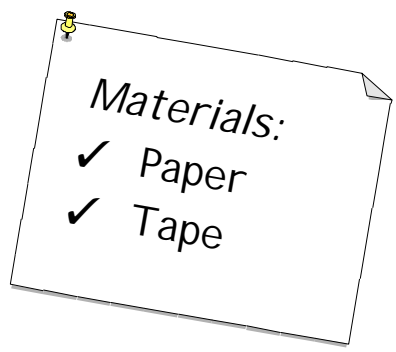

Team $\mathcal{A}$

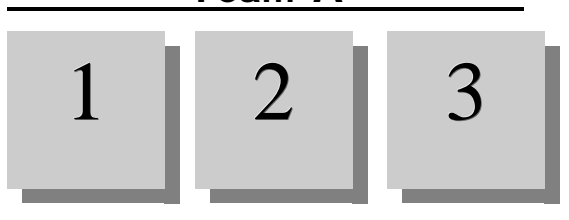

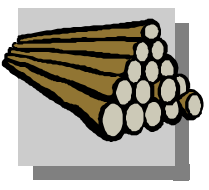

Team $\mathcal{B}$

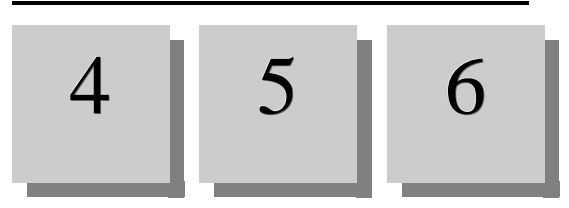

Have six youth stand on each numbered piece of paper. All participants should face the middle piece of paper. The youth to the left of the 6lank piece of paper are $\mathcal{T}$ am $\mathcal{A}$ (papers 1,2,3) and the youth to the right of the blankpiece of paper are Team $\mathcal{B}$ (papers 4, 5, 6). The object of the activity is for the members of Team $\mathcal{A}$ to switch places with the ir counterparts of Team $\mathcal{B}$. For example, Person 1 needs to end up where Person 4 was and vice versa. The two teams must work together to undo the log jam. The final placement should look like the figure below.

Te am $\mathcal{B}$
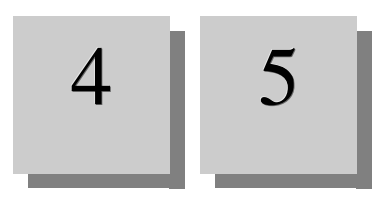

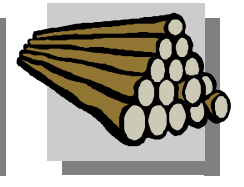

Team $\mathcal{A}$

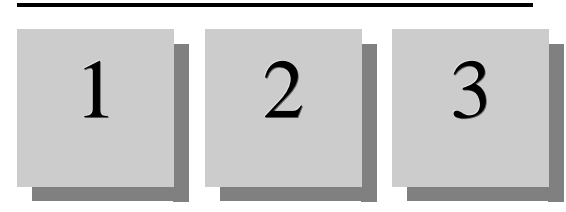

The rules are:

Everyone must be on a piece of paper at all times.

There can be only one person on a piece of paper at a time.

You can only move forward and only to an empty piece of paper.

You cango around one person at a time, only if there is an empty piece of paper befind them, and only if that person is on the other team.

After explaining the rules, answer any questions and then allow the game to begin.

Discussion questions:

Was the task difficult? Why or why not?

Did your group have a le ader? How did this work?

Did everyone contribute to the solution? Why or why not?

Activity Bank 48 
Te am Builder 4 - To Share or Not to Share?

Procedure: Before starting this activity, make a copy of the tasksheet for each group and be sure to have the mate rials needed to give out to each group.

Divide youth into 4 groups and pass out the appropriate mate rials to each group.

- Group 1: tape, 10 sheets of aluminum foil, 1 yellow sheet, 1 white sheet

- Group 2: tape, compass, 2 red sheets, 1 yellows heet,

- 1 white sheet

- Group 3:scissors, 1 white sheet, 2 6lue sheets, 1 yellows heet

- Group $4:$ glue, 1 blue sheet, 2 red sheets, ruler

Give each group a copy of the task sheet and explain that each group has a different set of materials but all groups must complete the same tasks. Between the four groups, there are enough materials for each group to comple te all tasks, if materials are used appropriately. Groups are allowed to bargain for materials. Besides what is passed out at the beginning of the activity, absolutely no other materials are to be used-this includes other items in the room or items that youth may have with them. The first group to complete all tasks correctly is the winner.

Feelfree to change the number of groups based on the number of youth you have. You will also have to adjust the materials given out and the tasks to be completed. The materials handed out to each group should be unequal but not so much so that one group feels comple tely helpless!

Discussion que stions:

How did it feel not to have all the materials you needed?

How did groups cooperate, compete, and bargain to get what they needed?

Task List:

1. Make a paper airplane at le ast 20" long that flies.

2. Make a flag of $3 " \chi 5$ " in at least three different colors.

3. Make a red hexagon with sides at le ast 2 "long.

4. Make a paper chain of at least three different colors.

5. Make a cube of aluminum foil with sides $2 " \times 2$ " $\times 2$ ". 


\section{Decision Makers}

These activities will help youth learn about making decisions and reaching a consensus as a group.

Decision Maker 1 - Add it Ulp

Procedure: Show the jar to the group and askeach per. son to guess the number of items in the jar. Have youth stay in their position and do not let them move around to observe the jar. Record the estimates on the board. Either you or one of your group should then calculate the average of the estimates and report it to the en. tire group.

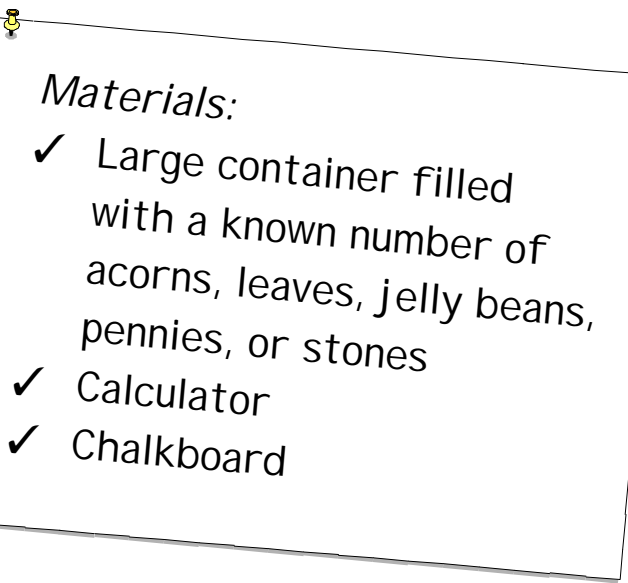

Allow youth to make a second guess and calculate the new average. Repeat this one or two more times, ending with one last individual guess. Disclose the actual number of ite $m s$ in the jar.

Discussion que stions:

How did your guesses change as a result of other people's guesses and the group ave rage?

If you changed your guess, did youget closer to the actual number? Do you feelyou made a better guess on your own or after listening to others?

Extended activity: You can use whatever type of ite mou want. I tems such as acorns and stones go along with the the me of the naturalenvironment but you can also use edi. ble items such as jelly beans, gumballs, or cookies!

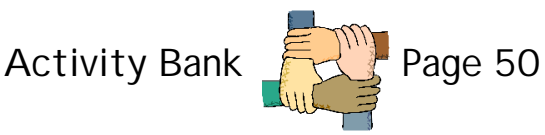


Decision Maker 2 - Decision Tree

Procedure: Decision trees provide a framework for looking at alternative projects. This activity is helpful when groups are investigating the feasibility of project ide as and trying to uncover alternative ideas.

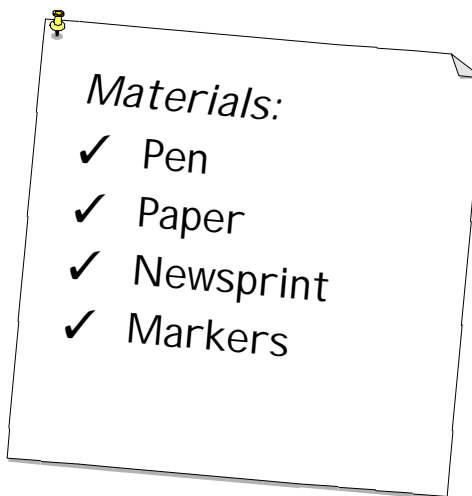

First, have the entire group identify a question as it relates to a se rvice project they are interested in doing. This initial question will form the trunk of the decision tree and should be a broad inquiry such as "S hould we build a nature trail?" or "S hould we landscape an area with native plants?" This first question of ten begins with the word 'should.'

Next, divide youth into groups of three or four people. Each group's task is to think about the decisions that need to be made about the identified project. The decision should be phrased in the form of a yes/no question and bothoptions (yes/no) should be discussed.

Each group is to represent the ir decisions and resulting alternatives pictorially in the form of a tree. As stated previously, the initial question is the trunk and each decision is a branching point. Each group should end up with several alternative futures for the entire group to discuss.

The sample decision tree on the next page should help clarify the process.

Discussion questions:

How difficult did you find this exercise? Were the re places where you got stuck?

Did you need to gather more information to comple te the tree?

How did this process change how you feel about the project idea?

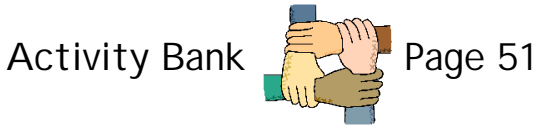




\section{Decision Tree- Prescribed Burning}

FutureC: Conduct educational programs on alternative methods.

\section{Future B: Find a way to make} educational programs possible

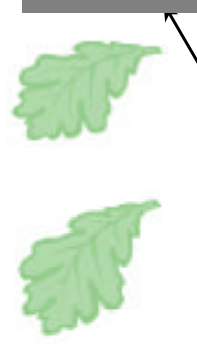

Can educational programs on alternative thinning methods be conducted?

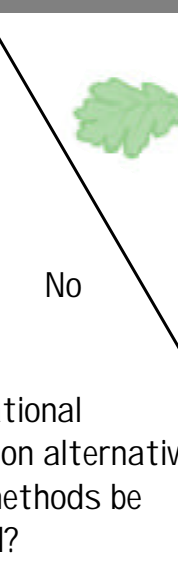

Is there community support for alternative vegetation clearing methods, like thinning or clearcutting?

Future D: Raise funds and find expertise to conduct alternative veget ation clearing methods.

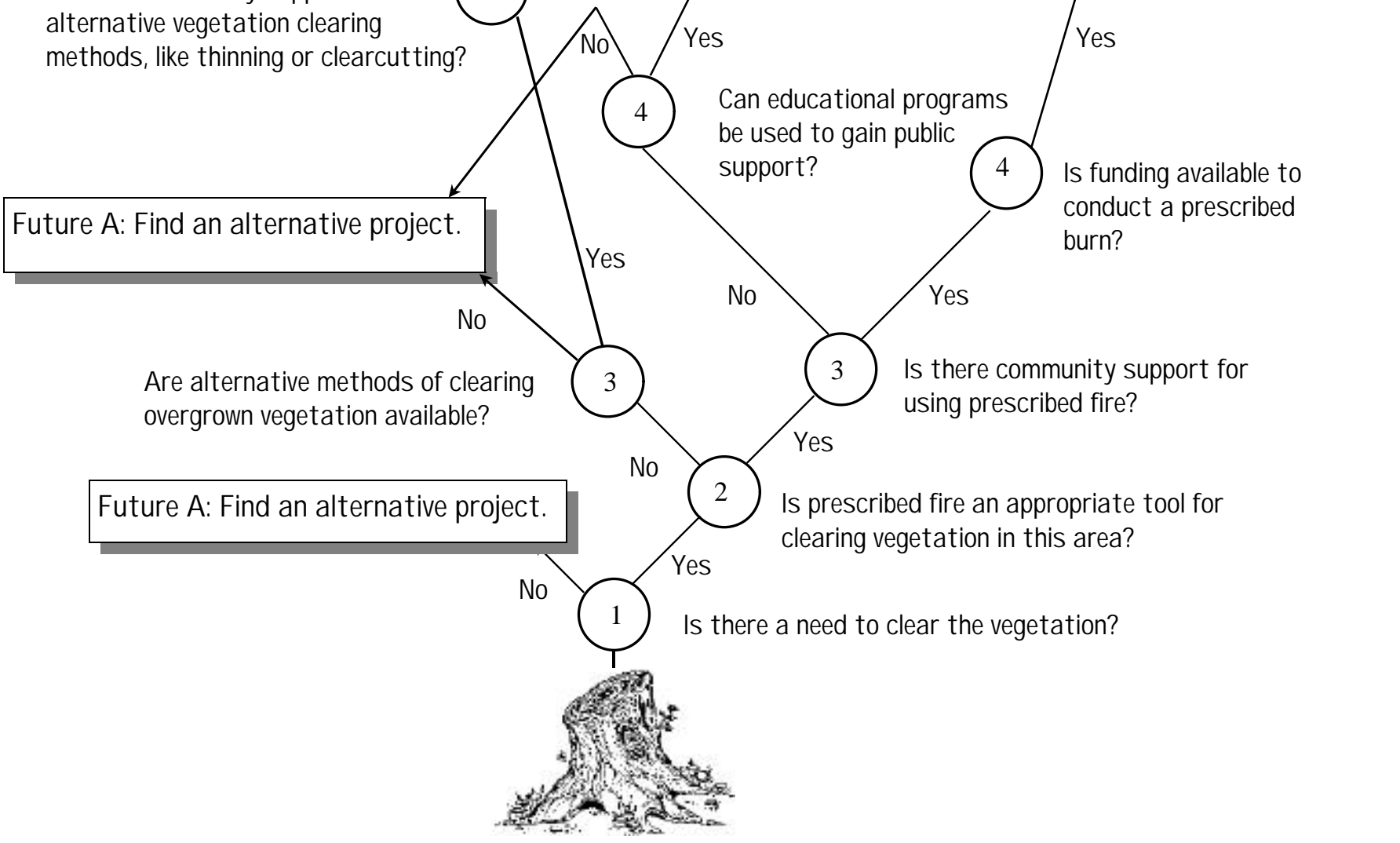

Should our project be using prescribed fire to clear overgrown veget ation? 


\section{Energizers}

Energizer activities are used to increase a group's energy and concentration or just improve the overall mood. Situations where energizers may be helpful are:

- youth are discussing a controversial issue and the nature of the discussion is becoming overly tense;

- youth seem bored and need a change of pace; and

- youth are working on one task and you need them to switch their attention to another activity.

Energizer 1 - Cle arcut

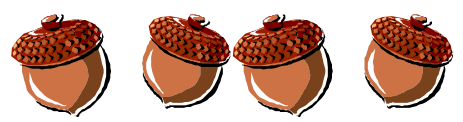

Procedure: Arrange chairs in a circle and have each me mber take a seat. You should stand in the middle of the circle and laMaterials:
$\checkmark$ Chairs for every.
one in the group beleach person as a "pine" or "oak." Explain that when you say "pine," all the people labeled as pines must get up and find a new seat. The same process should occur if you say "oaks" instead. If you say "clearcut", everyone must vacate their seat and find a newone. Repeat as many times as you like.

This is a simple, short activity that is meant to get people moving!

\section{Energizer 2 - Tree $\mathcal{T}$ wisters}

Materials:

$\checkmark$ Tree and plant

Procedure: Have youth form a circle. Explain that they will take identification turns saying a name of a plant. The rule is that the first letter of guides the plant must be the same as the last letter of the previous plant. Part of an example round might be:

$$
\text { gackpine }
$$

You can decide if names can be used more than once. If someone gets stuck encourage others to provide hints or suggestions. Also have tree and plant identification guides nearby in case everyone gets "stumped!"

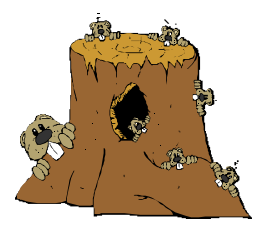


Energizer 3 - Running in Circles

Procedure: Explain to youth that they need to silently choose one person to be the ir "1" and another person to be their "2." The goal of the game is for each person to get as close to their "1" as possible, without touching them, and at the same time to stay as far away from the ir " 2 " as possible. Hint: This usually means keeping the ir " 1 " between themselves and the ir "2." After several minutes, call "reverse" and have youth switch the ir number 1 and 2 person.

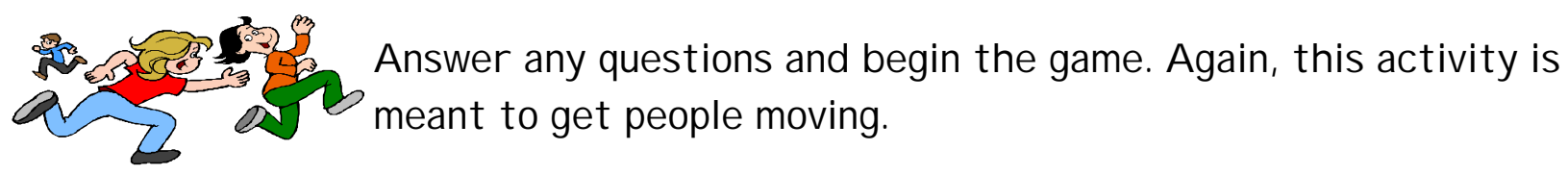

Energizer 4 - One at a Time

Procedure: Divide the group into two teams and have each team stand in a straight line. Give one deck of cards to the first person in each line. Explain that the object is to pass an entire deck of cards down the line as fast as possible.

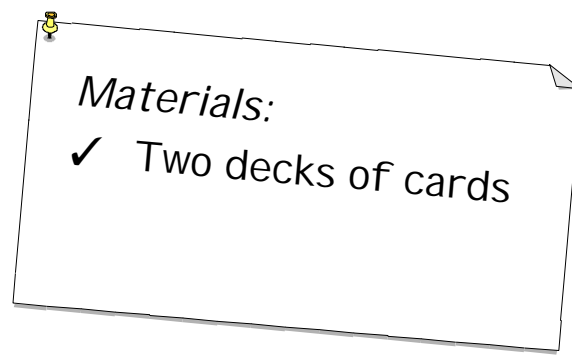

The first person must hold the deck of cards in their hand farthest from the rest of their team and with their other hand, pass the first card to the next person. This person must take the card in the ir first hand, pass it from one hand to another, then pass it to the third person. This continues until the entire deckreaches the last person in line.

The rule is that no person is to have more than one card at a time. You may want to have a practice round with three or four people to de monstrate. Whichever team gets the entire deck to the other end of their line first, wins.

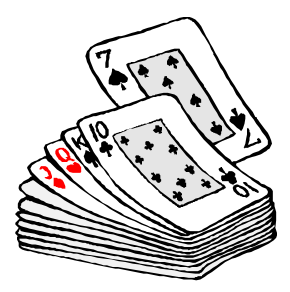




\section{Resources}

On the following pages, you will find contact information for agencies and organizations that can provide assistance. Belowe ach agency name, one or more symbols indicate what type of services are available.

(i) Information, often technical

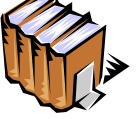

Curriculum and teacher resources

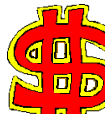

Grants and funding sources

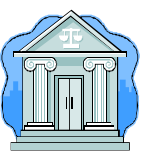

Regional offices

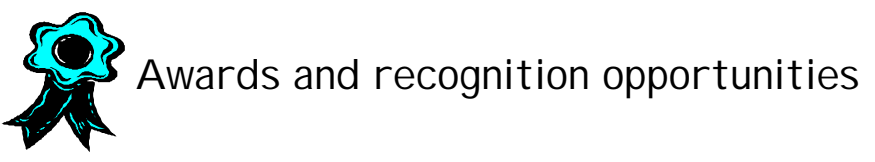

FEDERAL NATURAL RES OURCE AGENCIES

Bureau of Land Manage ment (B⿺M)

BLM manages more than 270 million acres of public lands, mostly in the Western United $S$ tates and Alaska. Originally these lands we re valued principally for the commodities extracted from them; today the public also prizes them for their recreationalopportunities and their natural, historical, and cultural resources. It is the mission of the Bure au of Land Manage ment to sustain the health, diversity, and productivity of the public lands for the use and enjoyment of present and future generations.

1849 CStreet, Room 406 - LS

Waskington, $\mathcal{D C} 20240$

Phone: (202) $452-5125$

http://www.6lm.gov

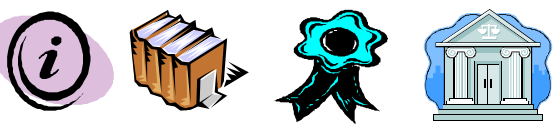


Environmental Protection Agency (EPA)

The mission of $\mathcal{E P A}$ is to protect human health and to safeguard the natural environment--air, water, and land--upon which life depends. The EPA we bsite offers great ide as about community service projects and information on the grants they offer.

1200 Pennsylvania Avenue, $\mathcal{N W}$

Waskington, $\mathcal{D C} 20460$

Phone:(202) $260-2090$

http://www.e pa.gov

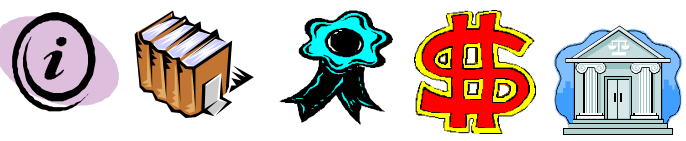

\section{$\mathcal{N}$ ational Park Service (NQPS)}

The NPS manages over 370 national parks, monuments, recreation areas, 6 at tefields, historic structures, parkways, and wild and scenic rivers. The $\mathcal{N}$ PS preserves natural and cultural resources and values of the national parksystem for the enjoyment, education, and inspiration of this and future generations. The Parks as Classrooms program engages students in park visits and programs.

1849 C S treet $\mathcal{N W}$

Wasfington, $\mathcal{D C} 20240$

Phone:(202) $208-6843$

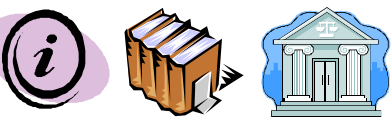

http://www.nps.gov

$\mathcal{N}$ atural Resources Conservation Service (NRCS)

$\mathcal{N R C S ~ h e l p s ~ p r i v a t e ~ l a n d o w n e r s ~ p r o t e c t ~ t h e ~ n a t u r a l ~ r e s o u r c e s ~ o n ~ t h e ~ i r ~ l a n d . ~ I t ~ e m p h a - ~}$ sizes science-based assistance and partnerships at the community level. The NRCS mission is to provide le adership in a partnership effort to help people conserve, improve, and sustain our natural resources and environment.

14 th and Independence Ave. SW

Wastington, $\mathcal{D C} 20250$

Phone: (202) $720-4525$ or 1-800-THE-SOIL

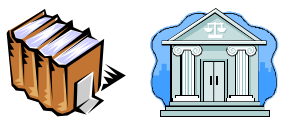

http://www.nrcs.usda.gov 
United States Fish and Wildlife Service (FWS)

$\mathcal{F W S}$ is the only agency of the Ul.S. Government whose primary responsibility is fish, wildlife, and plant conservation. The $\mathcal{F}$ WS helps protect a healthy environment for people, fish, and wildlife, and helps Americans conserve and enjoy the outdoors and our living treasures. The FW's major responsibilities are for migratory birds, endangered species, certain marine mammals, and freshwater fish.

1849 C S treet $\mathcal{N W}$

Wasfington, $\mathcal{D C} 20240$

Phone:(202) $208-4717$

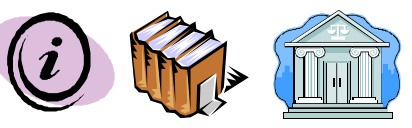

htt $p: / / w w w \cdot f w s \cdot g \circ v$

United States Geological $S$ urvey (US GS)

US GS provides reliable scientific information to describe and understand the Earth; minimize loss of life and property from natural disasters; manage water, biological, energy, and mineral resources; and enhance and protect the quality of life. US GS can provide a variety of high quality maps.

$12201 S$ unrise Valley Drive

Reston, VA 20192

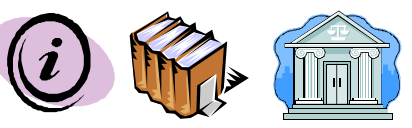

Phone: (703) 648-4000 or 1-888-AS K-US GS

http://www.usgs.gov

US DA Forest Service (FS)

US DA FS manages over 191 million acres of National Forests and Grasslands, assists non-Federal landowners through $S$ tate and Private Forestry programs, and conducts internationally recognized natural resources research. The job of $\mathcal{F S}$ managers is to help people share and enjoy the forest, while utilizing and conserving natural resources.

20114 th $S$ t. and Independence $\mathcal{A v e}$., $\mathcal{S} \mathcal{W}$

Washington, $\mathcal{D C} 20250$

Phone: (202) 205-1661

http://www.fs.fed.us

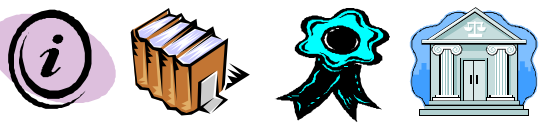




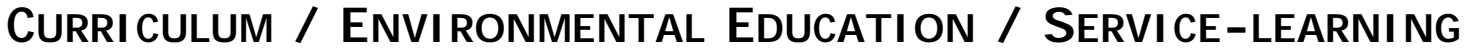

Constitutional Rights Foundation (CRF)

$C R \mathcal{F}$ is a non-profit, non-partisan, community-6ased organization de dic ated to educating America's young people about the importance of civic participation in a democratic society. CRF seeks to instill in our nation's youth a deeper understanding of citizenship through values expressed in our Constitution and its Bill of Rights, and educate the m to become active and responsible participants in our society.

601 South Kingsley Drive

Los Angeles, CA 90005

(213) $487.5590 \quad \mathcal{F a x}(213) 386.0459$

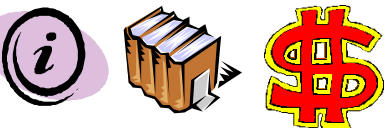

fttp://www.crf-usa.org

CRF's Robinson Mini-Grant Program awards grants for $\mathcal{K}-12$ service-le arning projects designed to address community issues. For more information go to: http://www.crf-usa. org/network/robinap200.html

Give Water a Hand

Give Water $\mathcal{A}$ Hand is a national watershed education program designed to involve young people in local environmental service projects. Following steps in the Give Water $\mathcal{A}$ Hand Action Guide, your youth group or class plans and completes a community service project to protect and improve water resources.

216 Agriculture $\mathcal{H a l l}$

1450 Linde $n$ Drive

Madison, WI 53706

Phone: (800) $928-3720$

http://www.uwex.edu/erc/gwah

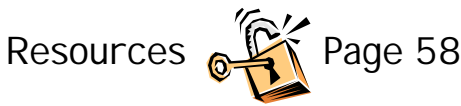


Learn and Serve America

Le arn and $S$ erve America supports service-learning programs in schools and community organizations that help nearly one million students from Kindergarten through college meet community needs, while improving their academic skills and learning the habits of good citizenship.

$1201 \mathcal{N}$ ew York Avenue, $\mathcal{N W}$

Washington, D.C. 20525

Phone:(202)606-5000

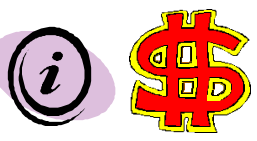

http://www.le arnandserve org

$\mathcal{N a t i o n a l} 4-\mathcal{H}$ Council

The National 4-H Council's mission is to be an uncommon youth de velopment organization fostering innovation and shared le arning for youth workers and young leaders.

7100 Connecticut Avenue

Che vy Chase, $\mathcal{M D} 20815-4999$

Phone: (301) 961-2800

http://www.fourficouncil.edu

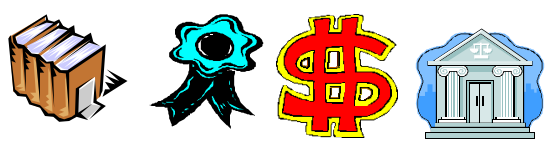

$\mathcal{N}$ ational Environmental Education and $\mathcal{T}$ raining Foundation ( $\mathcal{N}$ EETF)

$\mathcal{N E E T F}$ seeks to bring objective and scientifically sound environmental education to

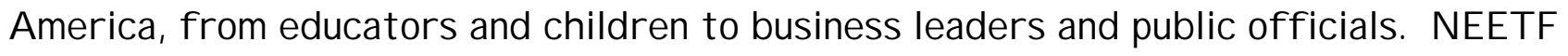
strives to help the nation meet critical challenges by connecting environmental le arning to progress on issues of national concern such as educationalexcellence, community participation in managing our natural resources, health care, and the environmental performance of small business.

$1707 \mathcal{H}$ Street, $\mathcal{N W}$ S uite 900

Wastington, $\mathcal{D C} 20009$

Phone: (202)833-2933

fttp://www.ne etf.org 
$\mathcal{N a t i o n a l}$ Service - Le arning Cle aringhouse

National Service-Learning Cle aringhouse is a comprehensive information system that focuses on all dimensions of service-le arning, covering kindergarten through figher education, school-based as well as community based initiatives.

ETRAssociates

P.O. Boх 1830

Santa Cruz, CA 95061

Phone: 1-866-245-7378

htt $p: / / w w w . s$ ervice le arning.org

$\mathcal{N a t i o n a l}$ Youth Leadership Council ( $\mathcal{N} \mathcal{Y} \perp \mathrm{C})$

$\mathcal{N Y L C ' s ~ m i s s i o n ~ i s ~ t o ~ e n g a g e ~ y o u n g ~ p e o p l e ~ i n ~ t h e i r ~ c o m m u n i t i e s ~ a n d ~ s c h o o l s ~ t h r o u g h ~ i n n o . ~}$ vation in le arning, service, leadership, and public policy. As one of America's most prominent advocates of service-learning and youth service, the $\mathcal{N} \mathcal{L C C}$ is at the forefront of efforts to reform education.

\section{West County Road $\mathcal{B}$}

S t. Paul, $\mathcal{M N} 55113$

Phone: (651) 631.3672

http://www.nylc.org

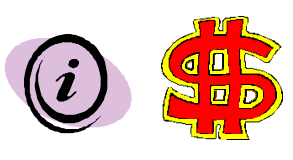

The NYLC operates the $\mathcal{N}$ ational Service-Learning Exchange. The Exchange has developed a network of over 300 volunteer Peer Mentors who have experience in service. le arning in different settings and who have volunteered to assist others.

Phone: 1-877-572-3924

http://www.lsaexchange.org

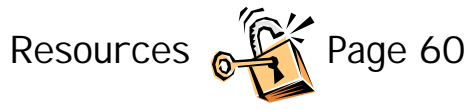


Project Learning Tree $(\mathcal{P L T})$

$\mathcal{P L T}$ is an interdisciplinary environmental education program for educators working with students in Pre Kthrough grade 12. PLI's mission is to increase students' understanding of our environment, stimulate students' critical and creative thinking, de velop students' ability to make informed decisions on environmental issues, and instill in students the commitment to take responsible action on be half of the environment.

$1111 \mathcal{N}$ ine teenth $S$ treet, $\mathcal{N W}$, S uite \# 780

Washington, $\mathcal{D C} 20036$

fit $\mathrm{p}: / / w w w . p l t . o r g$

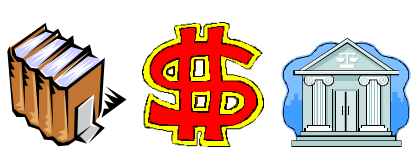

PLT has developed GreenWorks!, a Community Action and Service Learning Program designed to offer $\mathcal{P L T}$-educators and their students the opportunity to make a real difference in the communities in which they live and work. GreenWorks! encourages students to participate in community-6ased partnerships by developing and implementing action projects such as graffiti paint-overs, tree plantings, stream clean-ups, and recycling programs.

Project $\mathcal{W} \mathcal{E}$

Project $\mathcal{W E T}$ (Water $\mathcal{E} d u c$ ation for $\mathcal{T}$ eachers) is an international water science and education program for educators of students in grades $\mathcal{K} 12$. The goal of Project $\mathcal{W E T}$ is to facilitate and promote the awareness, appreciation, Knowledge, and stewardship of water resources through the development and dissemination of classroom-ready teaching aids and the establishment of state and internationally sponsored Project $\mathcal{W} \mathcal{E}$ programs.

210 Culbertson Hall, Montana S tate Univ.

Bozeman, $M \mathcal{M} 59717-0057$

Phone:(406) $994-5392$

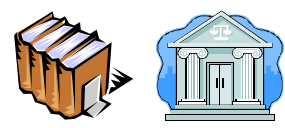

fittp://www.projectwet.org 
Project $\mathcal{W} I \mathcal{L D}$

Project $W I L D$ is a conservation and environmental education program for educators of students in kindergarten through high school. The program emphasizes wildlife--because of its intrinsic and ecological values, as well as its importance as a 6 as is for teaching how ecosystems function.

707 Conservation Lane, Suite 305

Gaithers6urg, Maryland 20878

Phone:(301) 527.8900

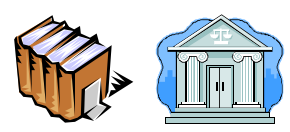

http://www.projectwild.org

Schoolgrants

The purpose of $S c h o o l g r a n t s$ is to provide resources for children, teachers/educators, and $\mathcal{K} 12$ schools. The ir goal is to contribute to the task of improving schools and pro. grams for the children served by those schools.

P.O. Box 4431

Dallas, $\mathcal{T} X 75208$

$\mathcal{H}$ t tp://www.schoolgrants.org

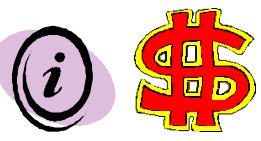

\section{$S \mathcal{E R} \mathcal{V}_{\text {Ene }}$ t}

$S \mathcal{E} \mathcal{V}$ Enet is a program of Youth Service America (YSA). A leader in the field of youth service for more than 10 years, YS $\mathcal{A}$ continues its tradition of ground-6reaking innovations in community service by supporting $S$ ERVEnet. S ERVEnet de pends and runs on the input of volunteers and organizations. It brings thousands of volunteers and community organizations together online daily.

110115 th $S$ treet, $\mathcal{N W}, S$ uite 200

Wasfington, $\mathcal{D C} 20005$

Phone: (202) 296-2992

http://www.servenet.org

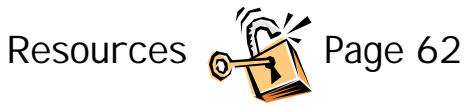




\section{ENVIRONMENT AL / NAT URAL RES O URCE ORGANIZATI ONS}

American Forests

American Forests'mission is to help people improve the environment with trees and forests. The organization works to provide a sustainable future for forests - both urban and rural - through national and international tree planting, forest policy, urban forestry, and popular programs, such as The National Register of Big Trees and Famous o Historic Trees.

P.O. Boх 2000

Wasfington, $\mathcal{D C} 20013$

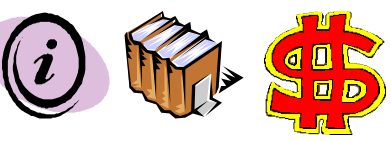

Phone:(202) $955-4500$

http://www.ame ricanforests.org

Elm Research Institute

Elm Research Institute promotes the planting of the Liberty elm, which is resistant to the Dutch elm disease. Their current goal is to have 1,000,000 healthy, thriving American elms lining the streets of $\mathcal{A} m e$ rica.

867 Route 12, Unit 5

Westmoreland, $\mathcal{N H} 03467$

Phone: 1-800-FOR-ELMS

http://www.forelms.org

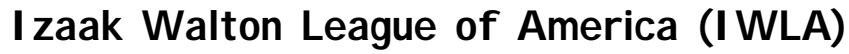

$I \mathcal{W} \mathcal{A}$ 's mission is to conserve, maintain, protect, and restore the soil, forest, water, and other natural resources of the United $S$ tates and other areas. The I WLA helps to educate the public about natural resources and the enjoyment and use of these resources.

707 Conse rvation Lane

Gaithersburg, $\mathcal{M D} 20878$

Phone: (301) $548-0150$
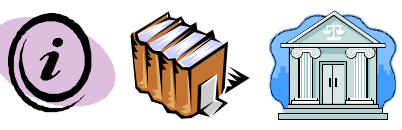

http://www.iwla.org 
Ke e $\mathrm{Ame}$ rican Beautiful Inc.

Ke e $p$ America Beautiful, Inc. focuses on enabling local volunteers to acquire the skills, tools, and resources to work together in building more beautiful, more active, and better quality communities. Their focus is on litter prevention, beautification and community improvement; and minimization of the impact of waste on communities.

1010 Was fington Boule vard

Stamford, Connecticut 06901

Phone: (203) $323-8987$

fittp://www.kab.org

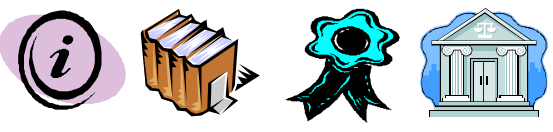

$\mathcal{N a t i o n a l}$ Audubon Society

The mission of the $\mathcal{N a t i o n a l} \mathcal{A} u d u b o n S o c i e t y$ is to conserve and restore natural ecosys. tems, focusing on birds and other wildlife, for the benefit of humanity and the earth's biological diversity.

$700 \mathcal{B r o a d}$ way

New York NV 10003

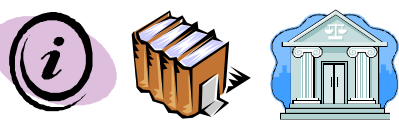

Phone: (212) 9793000

fttp://www.audubon.org

$\mathcal{N}$ ational Arbor Day Foundation

$\mathcal{N a t i o n a l} \mathcal{A r} 6$ or Day Foundation is the world's largest tree-planting environmental organization. It provides support, materials, education, and organization for tree planting projects.

100 Arbor Avenue

$\mathcal{N e} 6$ raska City, $\mathcal{N E} 68410$

Phone: 402-474-5655

fttp://www.arborday.org 
The National $\mathcal{T}$ ree $\mathcal{T}$ rust $(\mathcal{N} \mathcal{T} \mathcal{T})$

$\mathcal{N} \mathcal{T} \mathcal{T}$ mobilizes volunteer groups, promotes public awareness, provides grants, and unites civic and corporate institutions in support of local tree planting and education projects throughout the United States. The mission of the $\mathcal{N a t i o n a l}$ Tree $\mathcal{T}$ rust is to act as a catalyst for local volunteer groups in the growing, planting, and maintenance of trees in ruralcommunities, urban areas, and along our nation's highways.

$1120 \mathcal{G}$ street $\mathcal{N W}$, Suite 770

Wasfington, $\mathcal{D C} 20005$

Phone:(202) 628-8733

http://www.nationaltre etrust.org

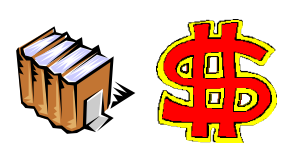

$\mathcal{N}$ ational Wildlife Federation ( $\mathcal{N} \mathcal{W} \mathcal{F})$

$\mathcal{N W} \mathcal{F}$ 's goal is to educate, ins pire, and assist individuals and organizations of diverse cultures to conserve wildlife and other natural resources and to protect the Earth's environment in order to achieve a peaceful, equitable, and sustainable future.

8925 Leesburg Pike

Vie nna, VA 22184

Phone: (800) 822-9919
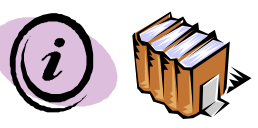

http://www.nwf.org

Sierra Club

Sierra Club's mission is to explore, enjoy, and protect the wild places of the earth; prac. tice and promote the responsible use of the earth's ecosystems and resources; educate and enlist humanity to protect and restore the quality of the natural and human environment; and use all lawful means to carry out these objectives.

85 Second Street, Second Floor

$S$ an Francisco, CA $94105-3441$

Phone: (4 15) 977.550

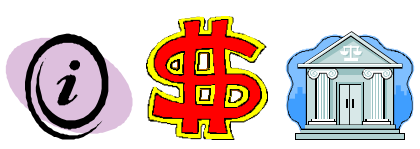

http://www.sie rraclub.org 
The Nature Conservancy $(\mathcal{T} \mathcal{N}(C)$

$\mathcal{T} \mathcal{N C}$ 's mission is to preserve the world's diverse plants, animals, and natural communities by protecting the habitats they need to survive. The Conservancy achieves this by purchasing the threatened land and waters that support these fragile ecosystems and endangered species.

$4245 \mathcal{N o r t h}$ Fairfax Drive, Suite 100

Arlington, VA $22203-1606$

Phone: $1.800-628.6860$

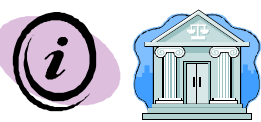

fttp://www.tnc.org

World Wild life Fund $(\mathcal{W} \mathcal{W} \mathcal{F})$

$\mathcal{W} \mathcal{W} \mathcal{F}$ is dedicated to protecting the world's wildlife and wildlands. W'WF directs its conservation efforts toward three globalgoals: protecting endangered spaces, saving endangered species, and addressing global threats.

P.O. Box 97180

Waskington, $\mathcal{D C} 20037$

Phone: 1-800-CALL-WWF

ft t p://www.world wild life org 
The American Forest or Paper Association (AFFPA)

$\mathcal{A F} \mathcal{P} \mathcal{A}$ is the national trade association of the forest, paper, and wood products industry. They represent member companies engaged in the growing, frarvesting, and process. ing wood and wood fiber; manufacturing pulp, paper, and paperboard products from both virgin and recycled fiber; and producing engine ered and traditional wood products.

$11111^{\text {th }}$ Street $\mathcal{N W}$, Suite 800

Wasfington, $\mathcal{D C} 20036$

Phone: (202) 463-2700

http://www.af andpa.org

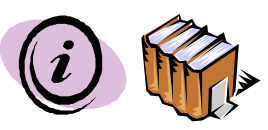

International Society of $\mathcal{A}$ rboriculture (ISA)

$I S \mathcal{A}$ is a professional organization where arborists share their experience and knowledge for the benefit of society. ISA helps to create a better understanding of trees and tree care through research and the education of professionals as well as globalef. forts to inform tree care consumers.

P.O. Boх 3129

Champaign, I $161826-312$

Phone: (217) 355-9411

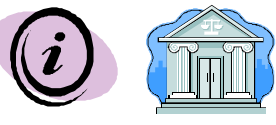

fttp://www.is a-arbor.com

$\mathcal{N}$ ational Association of Conservation Districts ( $(\mathcal{A} C D)$

$\mathcal{N A C D}$ is an organization that represents nearly 3,000 conservation districts across the nation. The mission of $\mathcal{N} \mathcal{A C D}$ is "to be an advocate for and to empower the nation's conservation districts to facilitate the harmonious use of our natural resources."

509 Capitol Court, $\mathcal{N} \mathcal{E}$

Waskington, $\mathcal{D C} 20002-4946$

Phone: (202) $547-\mathcal{N}(\mathcal{A C D}$ (6223)

fttp://www.nacdnet.org

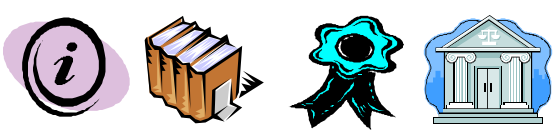


$\mathcal{N a t i o n a l}$ Association of $S$ tate Foresters

The $\mathcal{N a t i o n a l} \mathcal{A s s o c i a t i o n}$ of $\mathcal{S}$ tate Foresters is a nonprofit organization that represents the directors of the state forestry agencies from all fifty states, eight Ul.S. territories, and the District of Columbia. Their we bsite maintains a directory of $\mathcal{S}$ tate Foresters.

$444 \mathcal{N}$. Capitol $S$ treet, $\mathcal{N} \mathcal{W}, S$ uite 526

Wasfington, $\mathcal{D C} 20001$

Phone:(202)624-5976

http://www.s tateforesters.org

Society of American Foresters $(\mathcal{S A F})$

$S \mathcal{A F}$ is the largest professional society for foresters in the world. The mis sion of the Society of $\mathcal{A m e}$ rican Foresters is to advance the science, education, technology, and practice of forestry; to enhance the competency of its members; to establish profes. sional excellence; and to use the knowledge, skills, and conservation ethic of the profes. sion to ensure the continued health and use of forest ecosystems and the present and future availability of forest resources to benefit society.

5400 Grosvenor Lane

Bethesda, Maryland 20814

Phone: (301) $897-8720$

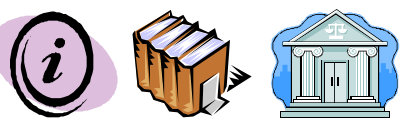

http://www.s af net.org

Tree Link

This we bsite was created to provide information, research, and ne tworking for people working in urban and community forestry. Their purpose is to inform, educate, and inspire.

c/o Tree Utah

364 E. Broadway

Salt Lake City, UT 84111

Phone: (801) 364-2122

http://www.tre elink.org

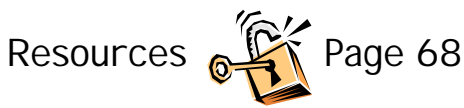




\section{$S \mathcal{T A T E} \mathcal{A N D}$ LOCAL RESOURCES}

For state and local resources, check the government pages in your telephone book to locate resources close to your home. Many of the national organizations listed previously have regional and state offices.

Every state has some type of natural resource agency. There may be a central agency that encompasses all the state's natural resources or separate agencies that deal with specific resources such as forests, wildlife, parks, and water.

The universities in your state can provide all sorts of information. Contact natural resources departments such as forestry, wildlife, soils, and horticulture. Cooperative Extension, Gased at your state's land grant university, has numerous resources and county extension offices.

The following types of agencies are likely to be listed in the localgovernment section of your phone book:

- Soil and water conservation districts. There are over 3,000 soil and water conservation districts across the country. These districts promote the wise use of soil and water resources and provide technical assistance and educational materials.

- $\quad$ Parks and recreation departments. These departments oversee the planning, maintenance, and operation of city and county parks that of ten include forested areas.

- City and county arborists. Many localgovernments employ tree experts to help plant and maintain the urban forest. City and county arborists can be great resource people in your local area.

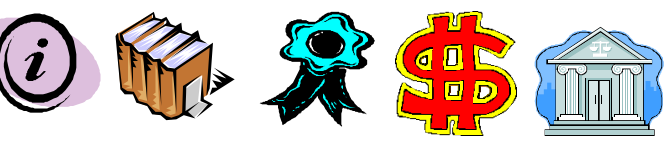


List additional resources here.

Resources 